\title{
Integrative proteomic analysis of the NMDA NR1 knockdown mouse model reveals effects on central and peripheral pathways associated with schizophrenia and autism spectrum disorders
}

Hendrik Wesseling ${ }^{1}$, Paul C Guest ${ }^{1}$, Chi-Ming Lee ${ }^{2}$, Erik HF Wong ${ }^{2}$, Hassan Rahmoune ${ }^{1}$ and Sabine Bahn ${ }^{1,3^{*}}$

\begin{abstract}
Background: Over the last decade, the transgenic N-methyl-D-aspartate receptor (NMDAR) NR1-knockdown mouse $\left(N R 1^{\text {neo-l-}}\right)$ has been investigated as a glutamate hypofunction model for schizophrenia. Recent research has now revealed that the model also recapitulates cognitive and negative symptoms in the continuum of other psychiatric diseases, particularly autism spectrum disorders (ASD). As previous studies have mostly focussed on behavioural readouts, a molecular characterisation of this model will help to identify novel biomarkers or potential drug targets.

Methods: Here, we have used multiplex immunoassay analyses to investigate peripheral analyte alterations in serum of $\mathrm{NR} 1^{\text {neo- } /-}$ mice, as well as a combination of shotgun label-free liquid chromatography mass spectrometry, bioinformatic pathway analyses, and a shotgun-based 40-plex selected reaction monitoring (SRM) assay to investigate altered molecular pathways in the frontal cortex and hippocampus. All findings were cross compared to identify translatable findings between the brain and periphery.

Results: Multiplex immunoassay profiling led to identification of 29 analytes that were significantly altered in sera of $N R 1^{\text {neo- } /-}$ mice. The highest magnitude changes were found for neurotrophic factors (VEGFA, EGF, IGF-1), apolipoprotein $A 1$, and fibrinogen. We also found decreased levels of several chemokines. Following this, LC-MS ${ }^{E}$ profiling led to identification of 48 significantly changed proteins in the frontal cortex and 41 in the hippocampus. In particular, MARCS, the mitochondrial pyruvate kinase, and CamKIl-alpha were affected. Based on the combination of protein set enrichment and bioinformatic pathway analysis, we designed orthogonal SRM-assays which validated the abnormalities of proteins involved in synaptic long-term potentiation, myelination, and the ERK-signalling pathway in both brain regions. In contrast, increased levels of proteins involved in neurotransmitter metabolism and release were found only in the frontal cortex and abnormalities of proteins involved in the purinergic system were found exclusively in the hippocampus.

Conclusions: Taken together, this multi-platform profiling study has identified peripheral changes which are potentially linked to central alterations in synaptic plasticity and neuronal function associated with NMDAR-NR1 hypofunction. Therefore, the reported proteomic changes may be useful as translational biomarkers in human and rodent model drug discovery efforts.
\end{abstract}

Keywords: ApoA1, Glutamate, Leptin, Major depressive disorder, Oligodendrocytes, Proteomics, Serum biomarkers, SRMstats

\footnotetext{
* Correspondence: sb209@cam.ac.uk

'Department of Chemical Engineering and Biotechnology, University of

Cambridge, Tennis Court Road, Cambridge CB2 1QT, UK

${ }^{3}$ Department of Neuroscience, Erasmus Medical Center, 3000 Rotterdam, CA,

The Netherlands

Full list of author information is available at the end of the article
}

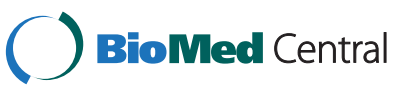

(c) 2014 Wesseling et al.; licensee BioMed Central Ltd. This is an Open Access article distributed under the terms of the Creative Commons Attribution License (http://creativecommons.org/licenses/by/4.0), which permits unrestricted use, distribution, and reproduction in any medium, provided the original work is properly credited. The Creative Commons Public Domain Dedication waiver (http://creativecommons.org/publicdomain/zero/1.0/) applies to the data made available in this article, unless otherwise stated. 


\section{Background}

The transgenic NR1-knockdown (NR1 $1^{\text {neo-/- }}$ ) mouse constitutively expresses only 5 to $10 \%$ of the essential N-methylD-aspartate receptor (NMDAR) NR1 subunit [1]. The NMDAR is crucial in neuronal development and physiology, and decreased levels or altered function of this receptor have been associated with the pathophysiology of schizophrenia (SZ) [2-5]. Consequently, the NR1 ${ }^{\text {neo-/- }}$ mouse has been widely used as a genetic model for intrinsic NMDAR hypofunction in preclinical drug discovery efforts. NR1 $1^{\text {neo-/- }}$ mice display hyperlocomotion and increased stereotypic behaviour, which represent standard behavioural readouts for the evaluation of animal models of SZ. These behavioural effects can be attenuated by the typical antipsychotic drug haloperidol, a potent highly specific $D_{2}$ dopamine receptor antagonist [6], and by the atypical antipsychotic drug clozapine [1], which affects a broader spectrum of neurotransmission systems $[7,8]$. In addition to these behavioural changes, NR1 $1^{\text {neo-/- }}$ mice also show significant impairments in spatial cognitive performance [9], reduced social interaction, escape behaviours, and actively avoid interaction with intruder males. Furthermore, $\mathrm{NR} 1^{\text {neo-l- }}$ males have been reported to be infertile due to their abnormal social behaviour. However, administration of clozapine has been found to ameliorate all of these symptoms [1], which are thought to predominantly reflect the negative and cognitive symptoms of SZ.

Interestingly, recent studies investigating the NR1 $1^{\text {neo-/- }}$ mouse identified behavioural and electrophysiological deficits relevant to all core symptoms of autism spectrum disorders (ASD) $[10,11]$. Further, clinical ASD symptomatology, including reduced prepulse-inhibition, auditory-evoked response $\mathrm{N} 1$ latency, and reduced gamma synchrony was observed in the NR1 $1^{\text {neo-/- }}$ mouse [12]. NMDAR NR1 subunit knockout in parvalbuminpositive interneurons resulted in an ASD-like phenotype [13] with impaired self-care and sociability [14] in the absence of depression-related behaviours [15]. In addition, NMDAR and glutamate abnormalities have been identified in various brain disorders, such as major depressive disorder [16,17] and ASD [18-20], which are characterized by negative symptom domains. The abovementioned behavioural data now supports the hypothesis of a potential role of impaired NMDAR function in the continuum of negative symptom phenotypes of a range of psychiatric disorders, including core features of autism [21].

Given these similarities, the primary objective of this study was to identify molecular signatures in the $\mathrm{NR} 1^{\text {neo-l- }}$ mouse model and to gain insights into the downstream molecular effects of glutamate dysfunction. A combination of three proteomic platforms was employed to explore a wide range of protein abundance changes in brain tissue and serum samples from the NR1 $1^{\text {neo-l- }}$ mouse model. Specifically, multiplex immunoassay profiling was used to assess serum changes given the high sensitivity of this method for quantification of low abundance circulating proteins such as cytokines, hormones, and growth factors. Label-free liquid chromatography mass spectroscopy in expression mode $\left(\mathrm{LC}-\mathrm{MS}^{\mathrm{E}}\right)$ analysis was used as this allows unbiased screening of approximately 1,000 proteins in a single extract and targets proteins, such as membrane receptors, nuclear factors, mitochondrial proteins, and cytoplasmic molecules, all of which have been implicated in psychiatric disorders. Finally, SRM mass spectrometry was used to target specific classes of proteins with greater sensitivity than the $\mathrm{LC}-\mathrm{MS}^{\mathrm{E}}$ approach. A secondary goal was to investigate whether changes in protein levels in serum can be linked to glutamatergic brain dysfunction, thus evaluating the translational utility of serum biomarker changes for psychiatric disorders.

\section{Methods}

\section{Animals}

The NR1 ${ }^{\text {neo-l- }}$ mice $[1,22,23]$ were obtained from the laboratory of Dr. Beverly Koller (The University of North Carolina at Chapel Hill) and a breeding colony was established at AstraZeneca Pharmaceuticals LP (Wilmington DE 19850, USA). All breeding and testing procedures were conducted in strict compliance with the "Guide for the Care and Use of Laboratory Animals" (Institute of Laboratory Animal Resources, National Research Council, 1996) and approved by the Institutional Animal Care and Use Committee of the University of North Carolina and AstraZeneca R\&D Montréal. The breeding and genotyping was performed as previously described [24-27]. It involved three populations of mice: $\mathrm{NR} 1^{\text {neo+/- }}$ heterozygotes maintained on C57BL/6 background (Jackson Laboratory), NR1 ${ }^{\text {neo+/- }}$ heterozygotes maintained on 129/ SvEv background (Taconic Farm), and an intercross between female C57BL/6 NR1 $1^{\text {neo+/- }}$ and male 129/SvEv $\mathrm{NR} 1^{\text {neo+/- }}$ to generate the F1 male NR1 $1^{\text {neo-/- }}$ and wildtype (WT) mice that were analysed in this study. Homozygotes carrying the NR1 hypomorphic mutation do not breed effectively. Therefore, the mutant homozygotes had to be generated by cross-breeding heterozygotic mice. The NR1 hypomorphic mutation could not be induced in pure C57BL/6 J or $129 \mathrm{SvEv}$ mice, because the mutants did not gain weight at the same rate as WT mice and the frequency of mutants born was less than expected. To overcome these problems, the strategy of breeding F1 hybrids was developed to generate the $N R 1^{\text {neo/neo }}$ mice [27]. Therefore, the progeny from the intercross were genetically identical F1 hybrids with the exception at NR1 locus: $50 \% \mathrm{NR} 1^{\text {neo+/- }}, 25 \% \mathrm{NR} 1^{\text {neo-/- }}$, and $25 \%$ WT. The following primers were used for genotyping: NR1 (+) fwd primer (intron 20) 5'TGA GGG GAA 
GCT CTT CCT GT3'; NR1 (-) fwd primer (neo) 5' GCT TCC TCG TGC TTT ACG GTA T3'; and NR1 common reverse primer (intron 20) 5'AAG CGA TTA GAC AAC TAA GGG T3'. Mice were housed on a $12 \mathrm{~h}$ light/dark cycle with access to food and water $\mathrm{ad}$ libitum. Mice (3 to 4 months old) were killed according to schedule, decapitated, and trunk blood was collected in ice-chilled tubes containing EDTA and centrifuged at $1,100 \mathrm{~g}, 4^{\circ} \mathrm{C}$, for $15 \mathrm{~min}$. The serum was immediately separated and stored frozen at $-80^{\circ} \mathrm{C}$ for later use. Brains were dissected on ice. Frontal cortex and hippocampus tissue were stored at $-80^{\circ} \mathrm{C}$.

\section{Multiplex immunoassay profiling}

Serum samples were analyzed using a rodent multianalyte profiling platform comprising multiplexed immunoassays of 75 analytes (Additional file 1: Table S2) in a Clinical Laboratory Improved Amendments (CLIA)-certified laboratory at Myriad-RBM (Austin, TX, USA), as described previously [28]. Immunoassays were calibrated using duplicate standard curves for each analyte and raw intensity measurements converted to protein concentrations using proprietary software. Multiplexed calibrators (eight levels per analyte) and controls (three levels per analyte) are developed to monitor key performance parameters, such as a lower limit of quantification, precision, cross-reactivity, linearity, spike-recovery, dynamic range, matrix interference, freeze-thaw stability, and short-term sample stability are established for every assay as described by the manufacturer (http://www. myriadrbm.com/technology/data-quality/). Data analyses were performed using the statistical software package $\mathrm{R}$ (http://www.r-project.org) and the analyte levels were determined. Analyses were conducted under blinded conditions with respect to sample identities and samples were analyzed in random order to avoid any sequential biases.

\section{Sample preparation}

Tissue samples were added to fractionation buffer containing $7 \mathrm{M}$ urea, $2 \mathrm{M}$ thiourea, 4\% CHAPS, 2\% ASB14, $70 \mathrm{mM}$ DTT, and protease inhibitor at a 5:1 (v/w) ratio [29]. Samples were sonicated (10 sec, 2 cycles) and vortexed at $4^{\circ} \mathrm{C}$ for $30 \mathrm{~min}$. Samples were then centrifuged at $17,000 \mathrm{~g}$ at $4^{\circ} \mathrm{C}$. Protein concentrations of the lysates were determined using a Bradford assay (Bio-Rad; Hemel Hempstead, UK). Approximately $100 \mu \mathrm{g}$ was precipitated using acetone. After dissolving the precipitate in $50 \mathrm{mM}$ ammonium bicarbonate, reduction of sulfhydryl groups were performed with $5 \mathrm{mM} \mathrm{DTT}$ at $60^{\circ} \mathrm{C}$ for $30 \mathrm{~min}$ and alkylation was carried out using $10 \mathrm{mM}$ iodacetamide, incubated in the dark at $37^{\circ} \mathrm{C}$ for $30 \mathrm{~min}$, and subsequently digested using trypsin at a 1:50 (w/v) ratio for $17 \mathrm{~h}$ at $37^{\circ} \mathrm{C}$. Reactions were stopped by the addition of $8.8 \mathrm{M} \mathrm{HCl}$ in a 1:60 (w/w) ratio. Quality control samples were prepared to monitor machine and preparation performance.

\section{Label-free LC-MS ${ }^{\mathrm{E}}$ analysis}

Brain tissue samples were analysed individually in technical duplicates. Splitless nano-ultra-performance liquid chromatography (UPLC) (10 kpsi nanoAcquity; Waters Corporation, Milford, MA, USA), was coupled online through a New Objective nanoESI emitter $(7 \mathrm{~cm}$ length, 10-mm tip; New Objective, Woburn, MA, USA) to a Waters Q-TOF Premier mass spectrometer. Data were acquired in expression mode $\left(\mathrm{MS}^{\mathrm{E}}\right)$ and the total continuous run time was 8 days. The procedure, quality assessment, and data processing were performed as described previously [30]. LC-MS ${ }^{\mathrm{E}}$ data were processed by the ProteinLynx Global Server (PLGS v.2.4 Waters, Milford, MA, USA) for ion detection, extraction, and identification using an ion accounting algorithm [31]. The Swiss-Prot rodent reference proteome database (2011-2013) was used for protein identification searches. To control the false discovery rate (FDR), data were searched against a decoy database, which was the randomised version of the database mentioned above to conserve amino acid frequencies. The FDR was set at the default maximum rate of $4 \%$, as applied before [32-35]. The search parameters were (i) enzyme = trypsin, (ii) fixed modification = carbamidomethylation of cysteines, (iii) variable modifications = oxidation of methionine and phosphorylation at serine, threonine, or tyrosine residues, (iv) initial mass accuracy tolerances $=10 \mathrm{ppm}$ for precursor ions and $20 \mathrm{ppm}$ for product ions, and (v) one missed cleavage allowed. In addition, the following criteria were used for protein identification: (i) $\geq 3$ fragment ions per peptide, (ii) $\geq 7$ fragment ions per protein, and (iii) $\geq 1$ peptide per protein. Raw data and PLGS search results were imported into the Rosetta Elucidator software (build 3.3.0.1.SP3.19, Rosetta Biosoftware; Seattle, WA, USA). Elucidator performed retention time (RT) and mz/charge alignment, feature identification, and extraction for all samples using the Rosetta PeakTeller algorithm. Dynamic background subtraction, smoothing in $\mathrm{RT}$, and $\mathrm{m} / \mathrm{z}$ dimension and isotopic region creation for peak-matching across all runs were calculated using an RT correction of $4 \mathrm{~min}$ at the maximum. A single data file was randomly chosen as the master, and all other sample files were aligned to the master in form of a dynamic RT shift. This procedure allowed the improved identification of peptides and proteins in each sample by taking the available data of all samples into account. Features were filtered for high score and normalized based on total ion current. Only peptides detected in both replicates and in $>80 \%$ of samples were included in further analysis. 
Protein abundance changes were determined using the MSstats package [36] based on linear mixed-effects models on the peptide intensities, following $\log _{2}$ transformation and exclusion of intensity values deviating more than three standard deviations from the mean of each group $(<1 \%$ of total data). Proteins were identified by at least two peptides. The $P$ values were adjusted to control the FDR at a cut-off of 0.05 following the Benjamini-Hochberg procedure [37].

\section{Protein set enrichment analysis}

Protein set enrichment analysis was carried out as previously described [38,39]. Significantly changed proteins were partitioned into three bins, according to their predicted fold-change (FC): FC $<1.0 ; \mathrm{FC}>1.0$, and $1<\mathrm{FC}$ $<1$. The $\mathrm{R}$ package database org.Mm.eg.db version 2.8 .0 was used for gene ontology (GO) term annotation based on entrez gene identifiers. Significant overrepresentation of an annotated GO term per bin was determined by the GOstats package [40]. For each bin, $P$ values for the GO categories [41] "biological pathway" and "cellular compartment" were calculated by a conditional hypergeometric test using the entire detected proteome as a background. These tests accounted for the hierarchical structure of the GO terms by first testing the "child terms" of any given GO category and filtering significantly enriched proteins prior to analysis of the "parent terms", as described previously [42]. This prevented the identification of directly-related GO terms with a considerable overlap of assigned proteins. GO terms with no significant enrichment in any bin $(P>0.05)$ and GO terms with less than two annotated proteins were removed. The remaining $P$ values greater than 0.05 were replaced by a conservative $P$ value of 1 . $P$ values were replaced by their negative logarithm to the base of ten and then converted to z-scores within their proteomic comparison for every remaining GO term. Finally, one-way hierarchical clustering using "Euclidean distance" as distance function and the "Average Linkage Clustering" method available in the software Genesis [43], was performed on all significantly enriched GO terms. The same enrichment analysis was repeated using KEGG pathway annotation in order to provide an independent in silico validation of our findings.

\section{Label-based selected reaction monitoring (SRM) mass spectrometry}

Abundance alterations of a panel of 39 candidate proteins implicated in the pathway analysis of the NR1 $1^{\text {neo-/- }}$ mouse (see results section) were measured using targeted SRM mass spectrometry on a Xevo TQ-S mass spectrometer (Waters Corporation) coupled online through a New Objective nanoESI emitter (7 cm length, 10-mm tip; New Objective) to a nanoAcquity UPLC system (Waters Corporation). The system was comprised of a C18 trapping column $(180 \mu \mathrm{m} \times 20 \mathrm{~mm}, 5 \mu \mathrm{m}$ particle size $)$ and a C18 $\mathrm{BEH}$ nano-column $(75 \mu \mathrm{m} \times 200 \mathrm{~mm}, 1.7 \mathrm{~mm}$ particle size). The separation buffers were (A) $0.1 \%$ formic acid and (B) $0.1 \%$ formic acid in acetonitrile. For separation of peptides, the following 48-min gradient was applied: 97/ $3 \%(\mathrm{~A} / \mathrm{B})$ to $60 / 40 \% \mathrm{~B}$ in $30 \mathrm{~min} ; 60 / 40 \%$ to $15 / 85 \%$ in $2 \mathrm{~min}$; $5 \mathrm{~min}$ at $15 / 85 \%$; returning to the initial condition in $1 \mathrm{~min}$. The flow rate was $0.3 \mu \mathrm{L} / \mathrm{min}$ and the column temperature was $35^{\circ} \mathrm{C}$.

SRM assays were developed following a general highthroughput strategy [44]. For method refinement, initially up to 12 unique peptides ranging from 6 to 20 amino acids in length, containing tryptic ends and no miscleavages were chosen for each of the selected proteins. All peptides containing amino acids prone to undergo modifications (e.g., Met, Trp, Asn, and Gln), potential ragged ends, lysine/arginine followed by proline or bearing the NXT/NXS glycosylation motif were generally avoided and only selected when no other options were available [45]. Peptides were checked by Protein BLAST (http://blast.ncbi.nlm.nih.gov/ Blast.cgi) searches to ensure uniqueness. For method refinement, up to 12 transitions per peptide were tested in SRM mode. Transitions were calculated using Skyline version 1.2.0.3425 [46] and corresponded to singly charged yions from doubly or triply charged precursors, in the range of 350 to 1,250 Da. Transitions were selected based on software internal predictions, discovery proteomics data, and spectral data available through the Human National Institute of Standards and Technology spectral libraries [47]. Method refinement was performed on quality control samples. For the final SRM assays, 2 to 3 peptides with the maximal intensities and highest spectral library similarity (dotp) per protein were selected. A further development step, analysing heavy-label spiked quality control samples in scheduled SRM mode, was used to confirm identity via coelution, extract the optimal fragment ions for SRM analysis, obtain accurate peptide retention times, and optimize collision energy and cone voltage for the quantification run applying skyline software (MacCoss Lab Software; Seattle, WA, USA) [46]. Heavy labelled forms of these selected peptides (spiketides L) were chemically synthesized via SPOT synthesis (JPT Peptide Technologies GmBH, Berlin, Germany). The final transitions, collision energy, and retention time windows used for each peptide can be found in the supplementary information (Additional file 2: Table S1).

Quantitative SRM measurements comparing NR1 $1^{\text {neo-l- }}$ and WT mice were performed in scheduled SRM acquisition mode with the optimized parameters defined during the assay refinement. For each target peptide a heavy isotope labelled internal standard (JPT Peptide Technologies $\mathrm{GmbH}$ ) was spiked in the peptide mixture for accurate quantification and identification. All SRM functions had a 2 min window of the predicted RT and scan times were $20 \mathrm{~ms}$, which ensured a dwell time of over $5 \mathrm{~ms}$ per 
transition. Assays were randomly split into three LC-SRM methods using Skyline software. This was done because of scheduling, assay development progress, and assay availability reasons. For each peptide, at least three transitions were monitored for the heavy and light version. Samples were run randomized and blocked [48] in triplicates and blanks and quality control peptide injections (yeast alcohol dehydrogenase, Additional file 2: Table S1) were performed alternating after every biological replicate. Resulting SRM data was analyzed using skyline and protein significance analysis was performed using SRMstats [49]. In the first step, data pre-processing was performed by transforming all transition intensities into $\log _{2}$-values. Then a constant normalization was conducted based on reference transitions for all proteins, which equalized the median peak intensities of reference transitions from all proteins across all MS runs and adjusted the bias to both reference and endogenous signals. Protein level quantification and testing for differential abundance among NR1 $1^{\text {neo-l- }}$ and WT mouse groups were performed using the linear mixedeffects model implemented in SRMstats. The scope of validity of our conclusions was restricted to the specific biological replicates in the experiments. Each protein was tested for abundance differences between NR1 ${ }^{\text {neo-/- }}$ and WT mouse. The $P$ values were adjusted to control the FDR at a cut-off of 0.05 according to Benjamini and Hochberg [37].

\section{Results}

\section{Serum characterisation - Quantitative serum immunoassay profiling}

We evaluated the peripheral adaption to the systemically reduced NMDAR-NR1 expression by analysing 75 analytes (Additional file 1: Table S2) in serum using a multiplex immunoassay platform. After principal component analysis data quality assessment and outlier filtering, the analysis resulted in the identification of 29 significantly altered molecules $(P<0.05)$ (Table 1$)$. The most prominent changes included a 17 -fold increase in apolipoprotein A1 (ApoA1), a 13-fold increase in fibrinogen, and an 8-fold increase in vesicular endothelial growth factor A (VEGF), as well as a 6-fold decrease in insulin-like growth factor 1 (IGF-1). The protein levels of all identified chemokines (Ccl12, Ccl11, Xcl1, Ccl7, and Ccl22) were significantly decreased.

\section{Brain characterisation - quantitative LC-MS ${ }^{\mathrm{E}}$ proteomic profiling of frontal cortex and hippocampus}

LC-MS ${ }^{\mathrm{E}}$ analysis resulted in the identification of 11,345 distinct peptides (563 proteins) in the frontal cortex and 14,775 distinct peptides (883 proteins) in the hippocampus after filtering the data using the criteria described in the Materials and Methods section. In the frontal cortex, 48 proteins were found to be significantly altered by more than 10\% (Figure 1, Additional file 3: Table S3). In the hippocampus, 41 proteins showed significant changes using the same criteria.

The EH domain-containing protein 4 (EHD4), adenylosuccinate synthetase isozyme (PURA1), guanine nucleotidebinding protein $\mathrm{G}(\mathrm{I}) / \mathrm{G}(\mathrm{S}) / \mathrm{G}(\mathrm{O})$ subunit gamma 12 (GBG12), myristoylated alanine-rich C-kinase substrate (MARCS), and selenium-binding protein 2 (SBP2) were identified as most significantly altered in the frontal cortex and synaptonemal complex protein 3 (SYCP3), asparagine synthetase [glutamine-hydrolyzing] (ASNS), NADH dehydrogenase 1 alpha subcomplex subunit 4 (NDUA4), and complexin 1 (CPLX1) were most significantly changed in the hippocampus. CaM kinase II subunit alpha (KCC2A) was detected as highly significantly reduced in both brain regions but showed a $10 \%$ decrease.

\section{Quantitative $L C-M S^{E}$ proteomic profiling-based pathway analysis}

Ingenuity pathway analysis (IPA) was performed using all significantly changed proteins $\left(P^{*}<0.05\right)$ in the frontal cortex (142 proteins) and hippocampus (227 proteins), regardless of the magnitude of change. This assumed that even slight variations in the levels of multiple proteins can result in pathway alterations. Using IPA, the protein changes were assigned to groups of biological functions in the Ingenuity knowledge base and z-scores were calculated as a prediction of whether a biological function was either up- or down-regulated. The biological functions underlying the identified molecular changes in the $\mathrm{NR} 1^{\text {neo-l- }}$ mouse are shown in Figure 2A. The frontal cortex showed a decrease in "coordination", "long-term potentiation", and "quantity of filaments". To a lesser extent, the behavioural domains of cognition, learning, and memory were decreased and hyperactive behaviour was increased. In the hippocampus a broader range of functions appeared to be affected. The most prominent finding here was an upregulation in "formation of cellular protrusions". Full information including proteins underlying these functions can be found in (Additional file 4: Table S4). Furthermore, we generated functional networks using IPA. Both networks suggested an involvement of the ERK pathway in the two regions. Functional annotation using the ingenuity upstream analysis tool revealed an inhibition of this pathway (Figure 2B).

In an attempt to further validate the IPA in silico findings, we carried out a GO-term based protein set enrichment analysis. We analysed whether specific GO terms reflecting either biological pathways, KEGG pathways, or cellular compartments were significantly over-represented in the datasets of significantly altered proteins using hypergeometric testing (Figure 3). We validated the involvement of "clathrin adaptor complex/coat assembly/ vesicle plasma membrane anchored proteins" and "longterm potentiation" in the frontal cortex, as well as "energy 
Table 1 Analysis of protein levels in serum of $\mathrm{NR}^{\text {neo-I- }}(n=12)$ and wildtype mice $(n=12)$ using multiplexed immunoassay

\begin{tabular}{|c|c|c|c|c|c|c|}
\hline \multicolumn{7}{|l|}{ A) } \\
\hline \multirow{2}{*}{$\begin{array}{l}\text { Protein Name } \\
\text { C-C motif chemokine } 12\end{array}$} & \multirow{2}{*}{$\begin{array}{l}\text { UniProt ID } \\
\text { Q62401 }\end{array}$} & \multirow{2}{*}{$\begin{array}{l}\text { Gene name } \\
\mathrm{Ccl} 12\end{array}$} & \multicolumn{2}{|c|}{ Ratio NR1/Wt } & \multirow{2}{*}{$\begin{array}{l}P \\
0.0002\end{array}$} & \multirow{2}{*}{$\begin{array}{l}P^{*} \\
0.0060\end{array}$} \\
\hline & & & $\boldsymbol{\nabla}$ & 0.52 & & \\
\hline Insulin-like growth factor I (IGF-I) & P05017 & $\operatorname{lgf1}$ & $\boldsymbol{\nabla}$ & 0.16 & 0.0002 & 0.0060 \\
\hline Osteopontin (2AR) & P10923 & Spp1 & $\boldsymbol{\nabla}$ & 0.36 & 0.0003 & 0.0060 \\
\hline Interleukin-12 subunit alpha (IL-12A) & P43431 & IL12A & $\boldsymbol{\Delta}$ & 1.86 & 0.0004 & 0.0060 \\
\hline Vascular endothelial growth factor A (VEGFA) - assay 1 & Q00731 & Vegfa & $\Delta$ & 7.41 & 0.0004 & 0.0060 \\
\hline - assay 2 & & & $\Delta$ & 8.26 & 0.0006 & 0.0061 \\
\hline von Willebrand factor (vWF) & Q8CIZ8 & Vwf & $\Delta$ & 2.98 & 0.0005 & 0.0061 \\
\hline Fibrinogen, alpha polypeptide (Protein Fga) & Q99K47 & Fga & $\boldsymbol{\Delta}$ & 13.19 & 0.0007 & 0.0061 \\
\hline Apolipoprotein A-I (ApoA1) & Q00623 & Apoa1 & $\Delta$ & 16.77 & 0.0007 & 0.0061 \\
\hline C-X-C motif chemokine 5 (Cytokine LIX) & P50228 & $\mathrm{CxCl5}$ & $\boldsymbol{\nabla}$ & 0.75 & 0.0023 & 0.0143 \\
\hline Eotaxin (C-C motif chemokine 11) & P48298 & Ccl11 & $\boldsymbol{\nabla}$ & 0.50 & 0.0024 & 0.0143 \\
\hline Lymphotactin (C motif chemokine 1) & P47993 & Xcl1 & $\boldsymbol{\nabla}$ & 0.56 & 0.0025 & 0.0143 \\
\hline Clusterin (Apolipoprotein J) & Q06890 & $\mathrm{Clu}$ & $\boldsymbol{\nabla}$ & 0.61 & 0.0028 & 0.0152 \\
\hline Macrophage colony-stimulating factor 1 (CSF-1) & P07141 & Csf1 & $\Delta$ & 1.65 & 0.0031 & 0.0156 \\
\hline Immunoglobulin A (lgA) & NA & NA & $\boldsymbol{\nabla}$ & 0.75 & 0.0035 & 0.0158 \\
\hline Glutathione S-transferase Mu 1 & P10649 & Gstm1 & $\Delta$ & 1.57 & 0.0036 & 0.0158 \\
\hline Leptin (Obesity factor) & P41160 & Lep & $\boldsymbol{\nabla}$ & 0.49 & 0.0051 & 0.0206 \\
\hline C-C motif chemokine 7 (MCP-3) & Q03366 & $\mathrm{Ccl} 7$ & $\boldsymbol{\nabla}$ & 0.51 & 0.0052 & 0.0206 \\
\hline Interleukin-1 beta (IL-1 beta) & P10749 & $\mathrm{IL} 1 \mathrm{~B}$ & $\boldsymbol{\nabla}$ & 0.58 & 0.0103 & 0.0358 \\
\hline Adrenocorticotropic hormone (ACTH) & P01193 & Pomc & $\nabla$ & 0.58 & 0.0105 & 0.0358 \\
\hline Oncostatin-M (OSM) & P53347 & Osm & $\Delta$ & 2.15 & 0.0114 & 0.0370 \\
\hline Glucagon & P55095 & Gcg & $\Delta$ & 1.42 & 0.0202 & 0.0612 \\
\hline CC chemokine DC/B-CK (Chemokine (C-C motif) ligand 22) & Q546S6 & $\mathrm{Ccl} 22$ & $\boldsymbol{\nabla}$ & 0.82 & 0.0210 & 0.0612 \\
\hline Interleukin-11 (IL-11) & P47873 & $\| 11$ & $\boldsymbol{\Delta}$ & 1.52 & 0.0212 & 0.0612 \\
\hline Epidermal growth factor (EGF) - assay 1 & P07522 & Egf & $\Delta$ & 2.42 & 0.0235 & 0.0654 \\
\hline - assay 2 & & & $\boldsymbol{\Delta}$ & 2.12 & 0.0287 & 0.0718 \\
\hline Myeloperoxidase (MPO) & P11247 & Mpo & $\Delta$ & 1.53 & 0.0246 & 0.0659 \\
\hline Tumor necrosis factor (TNF-alpha) & P06804 & Tnf & $\boldsymbol{\Delta}$ & 1.66 & 0.0283 & 0.0718 \\
\hline Coagulation factor VII & P70375 & F7 & $\boldsymbol{\nabla}$ & 0.86 & 0.0309 & 0.0748 \\
\hline Neutrophil gelatinase-associated lipocalin (NGAL) & P11672 & Len2 & $\Delta$ & 3.27 & 0.0443 & 0.1038 \\
\hline Endothelin-1 (ET-1) & P22387 & Edn1 & $\boldsymbol{\nabla}$ & 0.72 & 0.0473 & 0.1075 \\
\hline
\end{tabular}

The table includes Uniprot ID, gene names, ratios (calculated based on average), $P$ values (Mann-Whitney U-test), and adjusted $P$ values ( $P^{*}$, Benjamini-Hochberg corrected). Significant analytes with an increase/decrease greater than 5-fold are highlighted in bold.

$\boldsymbol{\nabla}$ downregulated, $\boldsymbol{\Delta}$ upregulated.

metabolism", "purine metabolism", and "apoptosis" in the hippocampus.

\section{Validation of significantly changed functional pathways}

As a next step, we focussed on the core identified significantly altered pathways and biological functions using SRM, a highly sensitive targeted proteomic method, as an orthogonal validation method of the reported results. We developed an assay panel incorporating proteins involved in the ERK-pathway, clathrin-mediated endocytosis, glutamatergic signal transduction/transport, and energy metabolism. Furthermore, cell-type-specific markers were included. Using SRM we were able to validate most of the significantly altered pathways identified by label-free LC-MS ${ }^{\mathrm{E}}$ (Table 2).

In the $\mathrm{LC}-\mathrm{MS}^{\mathrm{E}}$ phase of the study, we were unable to detect any of the NMDA receptor subunits for quantitative analysis, most likely due to the lower sensitivity of 


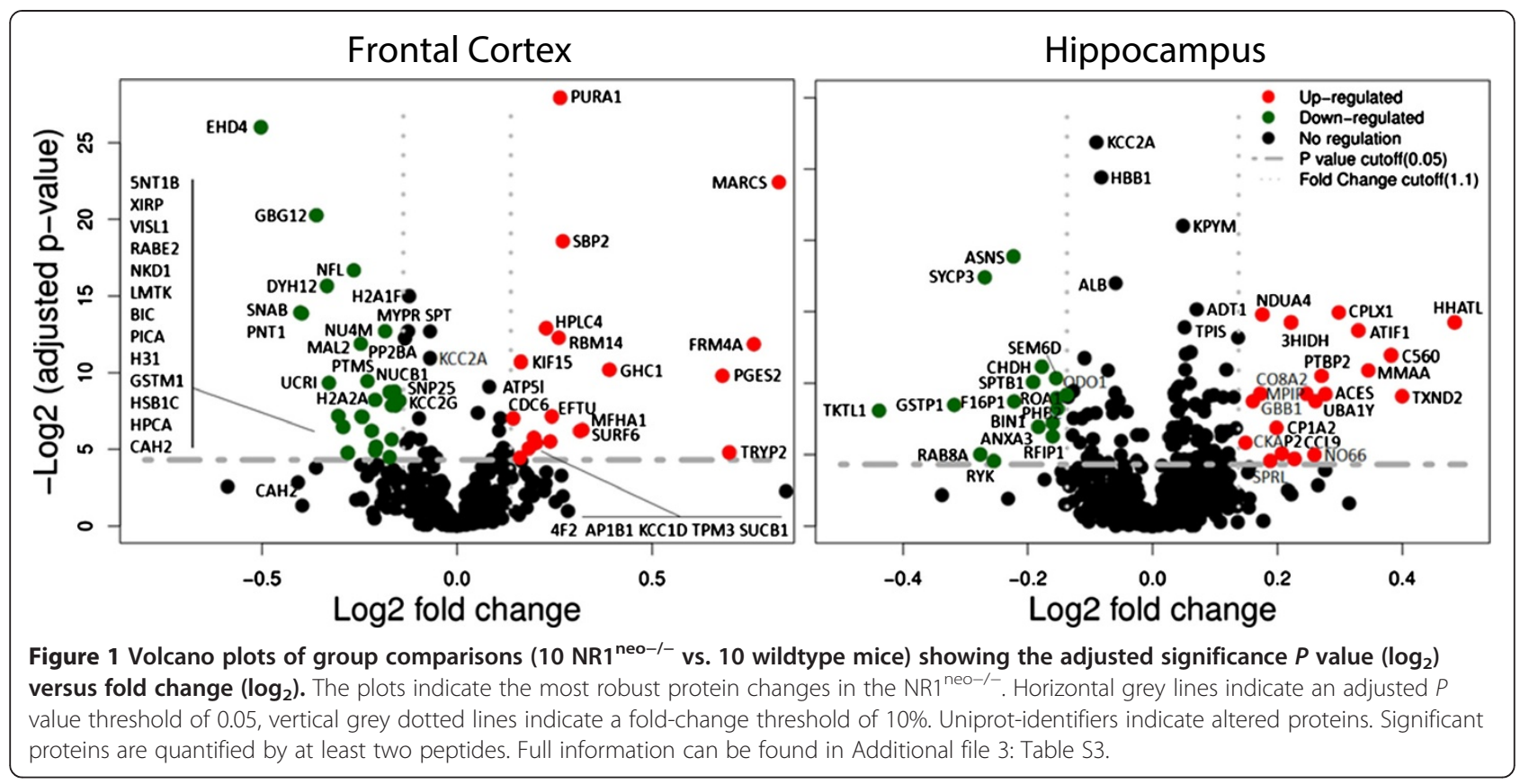

this approach. However, we were able to detect the NR1 subunit using SRM and this revealed a significant decrease in this protein in both the frontal cortex (ratio $=0.26$ ) and hippocampus (ratio $=0.16$ ). In contrast, no changes in other glutamate receptors (GluR-1, GluR-2, GluR-3) were detected in either tissue. In the frontal cortex, abnormalities in neurotransmitter metabolism and transport was indicated through significant abundance changes in the key enzymes glutamate decarboxylase 2, GABA aminotransferase, and the vesicular glutamate transporter 1 . Furthermore, clathrin-mediated endocytosis was found to be increased, oligodendrocytic markers decreased, and long-term potentiation altered. In the hippocampus, an alteration in purine metabolism could be confirmed as well as changes in long-term potentiation. The ERK-pathway appeared to be affected in both frontal cortex and the hippocampus, as suggested earlier through pathway analysis.

\section{Discussion}

Herein, we present the first comprehensive proteomic study characterising central and peripheral changes in the NR1 ${ }^{\text {neo-l- }}$ mouse model. We employed orthogonal quantitative proteomic approaches to investigate protein alterations in serum that can serve as surrogate or translational biomarkers for decreased NMDAR function. The findings associated with NMDAR hypofunction in hippocampus and frontal cortex brain tissue may aid in the discovery of novel drug targets and in elucidating affected downstream pathways. Currently, animal models are almost exclusively assessed using behavioural readouts, leaving questions as to the underlying cellular and molecular network alterations unanswered.
Using multiplex immuno-profiling to measure peripheral metabolic, neurotrophic, and immunological factors, we initially linked the NMDA-mediated glutamatergic hypofunction to several serum analyte alterations. Interestingly, eight out of the 29 changing proteins (ApoA1, coagulation factor-VII, EGF, IGF-1, leptin, TNF $\alpha$, VEGF, vWF) have previously been reported as changed in SZ and five (ApoA1, Eotaxin, EGF, Leptin, TNF $\alpha$,) in ASD biomarker studies [50-54]. This supports the notion that serum changes reflect aspects of the pathophysiology associated with psychiatric disorders; providing evidence for the translational utility of serum biomarker studies and their potential for personalised medicine approaches.

The strongest alteration was a 17 -fold increase in levels of the lipid transport protein ApoA1. Although ApoA1 has not been linked to effects on glutamatergic signalling before, it is one of the most robust serum biomarkers in SZ [55,56], despite or whereas or even though this has been mainly found to be decreased in CSF, brain, and peripheral tissues of patients. The reason for this apparent discrepancy may be due to adaptive responses which are specific to the NR1 $1^{\text {neo-/- }}$ mouse model. ApoA1 plays a role in cholesterol transport and has been shown to prevent learning and memory deficits in an Alzheimer's disease mouse model by attenuating neuroinflammation [57]. We also found similar strong increases in fibrinogen, implicating alterations in the blood coagulation system, as well as VEGF, which is produced by neuronal and glial cells in the developing nervous system and directly stimulates neuronal functions such as neurogenesis and cell survival in culture and in vivo [58]. This might be linked to our findings in 


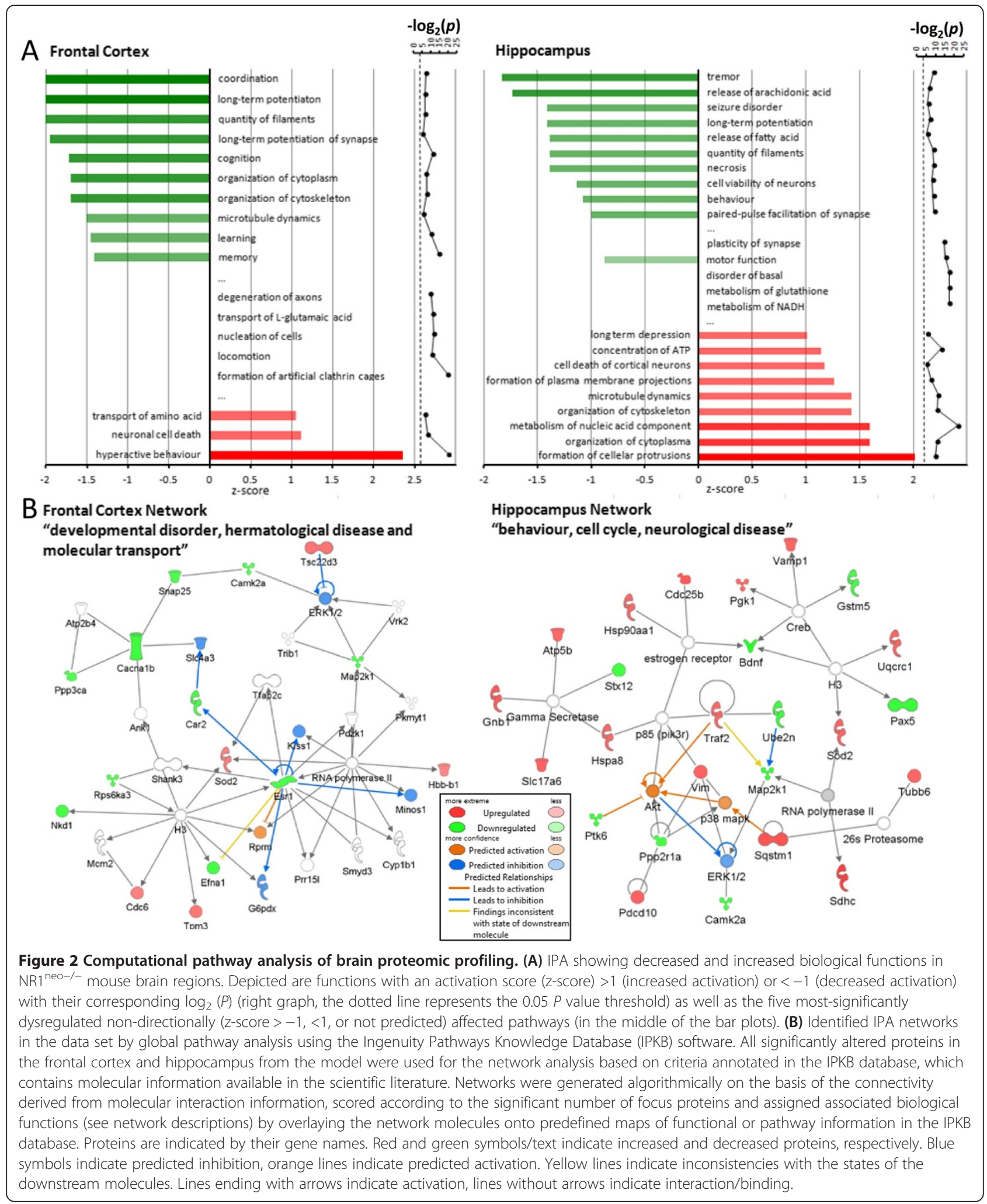

frontal cortex tissue of increased levels of synaptic proteins, indicating increased neuro- and synaptogenesis, which was confirmed by $\mathrm{LC}-\mathrm{MS}^{\mathrm{E}}$, SRM, and computational pathway analysis (Table 2). Synapse formation, maintenance, and plasticity are critical for the correct function of the nervous system and its target organs. During development, these 


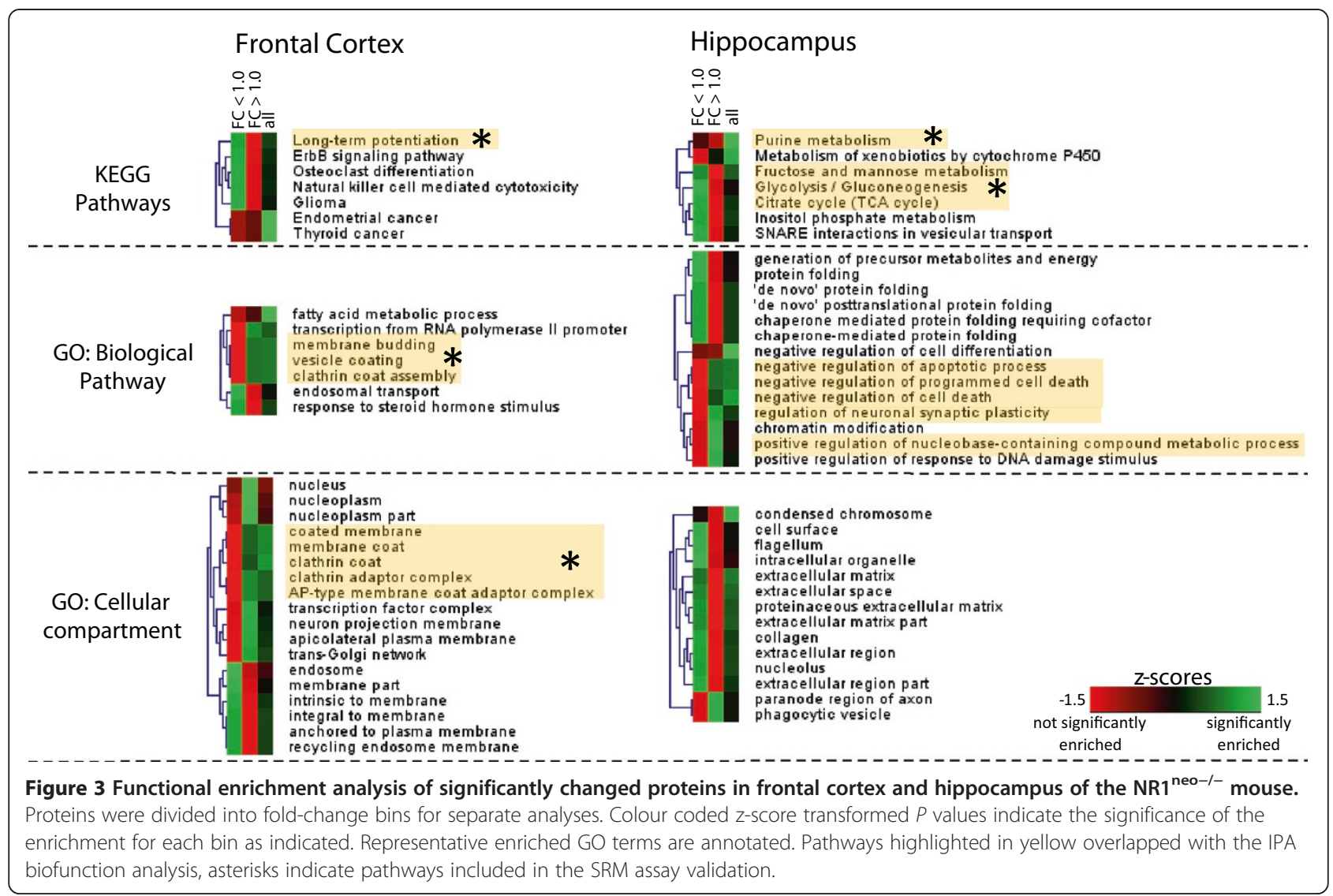

processes enable the establishment of appropriate neural circuitry. In parallel with the increased synaptic markers, we found an increase in proteins involved in neurotransmitter metabolism and transport in the frontal cortex. These findings provide further evidence for increased excitability and imbalance in the frontal cortex, resembling neurochemical changes which are characteristic of SZ [59,60], ASD [61-64], and other disorders with negative symptom domains. At the mechanistic level, VEGF has been shown to exert its neurotrophic properties by regulating NMDAR activity via the SRC family kinase (SFK) pathway [65]. The SFK pathway stimulates signalling events in neuronal cell types, including activation of phospholipase C-gamma, AKT, and ERK. We found abnormal ERK signalling in both brain regions. Therefore, further studies are warranted to investigate the connection of NMDAR and VEGF signalling. Our findings suggest that one or more components of the VEGF signalling pathway might constitute a new therapeutic target for the treatment of SZ and potentially other psychiatric disorders.

This is also the first study linking NMDA-mediated glutamate dysfunction to decreased serum levels of IGF1. At the circulatory level, IGF-I promotes cell differentiation and growth and may also function as an anti-apoptotic agent [66]. Lower levels of IGF-1 have been found in serum of antipsychotic-naive [67] and antipsychotic-treated SZ patients [68], as well as in children with ASD [69-71]. A recent study reported a relationship between negative symptoms and IGF-1 plasma levels in first episode SZ [72]. Centrally, IGF-1 plays a major role in early brain development, neuro- and synaptogenesis, secretion of various neurotransmitters and myelination processes [73-75]. Remarkably, IGF-1 treatment restores synaptic deficits in neurons from $22 \mathrm{q} 11.2$ deletion syndrome patients, a syndrome characterized by an increased risk of SZ and ASD [76], as well as in a SHANK3-deficient mouse model of autism [77]. Thus, we suggest that drugs which target the IGF-1 pathway should be evaluated for the treatment of psychiatric disorders associated with impaired glutamate function. One limitation of the multiplex immunoassay profiling stage of the study is the potential bias in the selection and the molecular class assignment of the investigated molecules. These assays were based on commercial availability and therefore only targeted selected classes of regulatory molecules. Therefore, it is possible that a different selection of molecules would lead to different conclusions from those drawn in this study.

Possibly reflecting IGF-1 function, we found an increase in synaptic markers in the frontal cortex and decreased levels of myelin-specific proteins in the frontal 
Table 2 Significantly changed proteins identified using label-based LC-SRM in the frontal cortex and hippocampus of the NR1 ${ }^{\text {neo-l- }}(n=12)$ compared to wildtype mice $(n=12)$

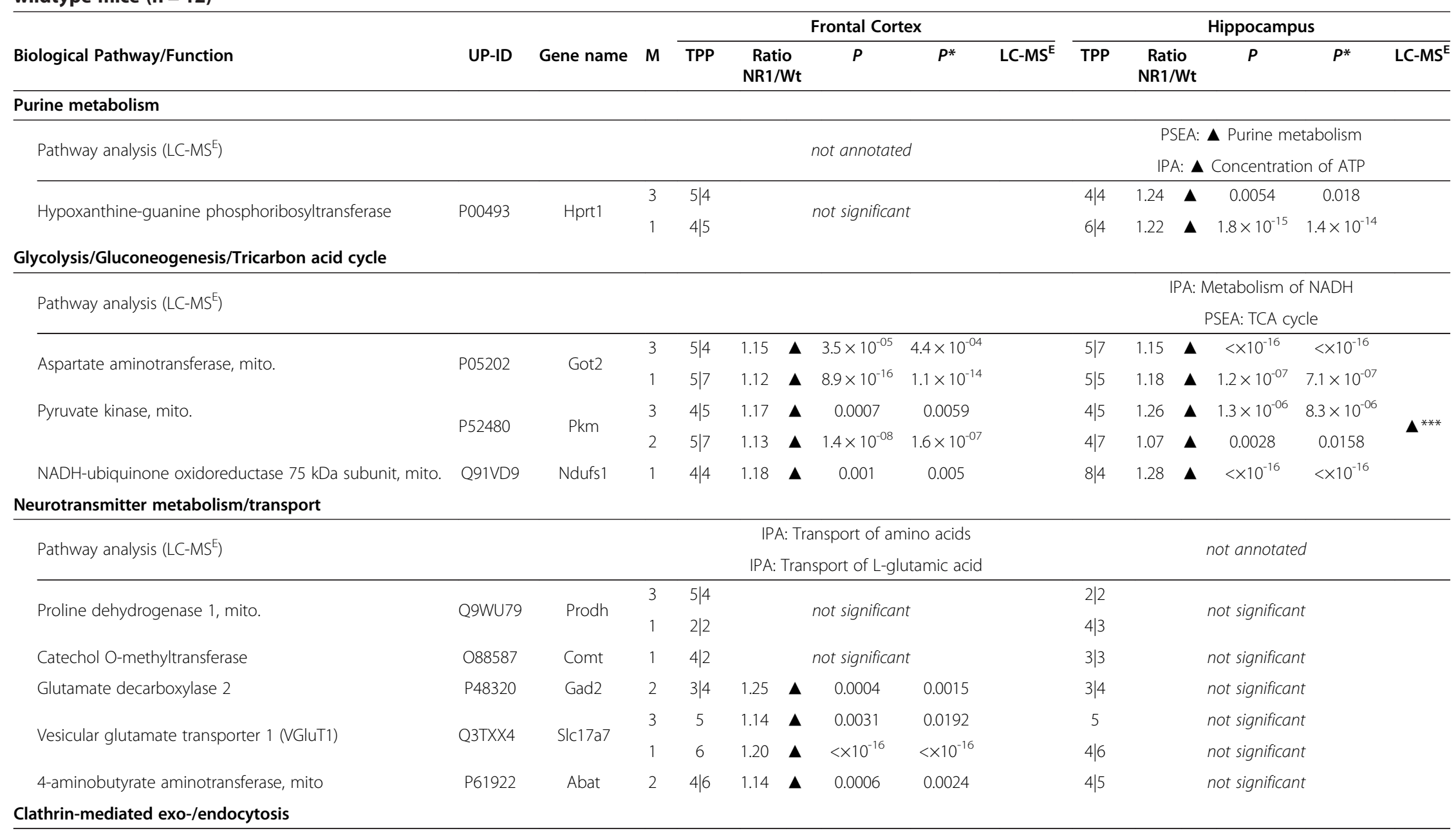

Clathrin-mediated exo-/endocytosis

Pathway analysis (LC-MS $)^{\mathrm{E}}$

PSEA: $\boldsymbol{\Lambda}$ Vesicle coating, $\boldsymbol{\Lambda}$ Membrane budding

PSEA: $\boldsymbol{\Lambda}$ Clathrin coated pit etc.

not annotated

IPA: $\Delta$ Formation of artificial clathrin cages

\begin{tabular}{|c|c|c|c|c|c|c|c|c|c|c|c|c|c|}
\hline AP-2 complex subunit alpha-1 & P17426 & Ap2a1 & 1 & $5 \mid 6$ & 1.13 & $\Delta$ & $6.5 \times 10^{-08}$ & $5.2 \times 10^{-07}$ & $6 \mid 6$ & & not significant & & $\mathbf{\Delta}^{*}$ \\
\hline Synaptojanin & Q8CHC4 & Synj & 2 & $3|5| 3$ & 1.08 & $\Delta$ & 0.017 & 0.041 & $5|5| 5$ & & not significant & & \\
\hline Synapsin-1 & O88935 & Syn1 & 2 & $6|4| 3$ & 1.11 & $\Delta$ & 0.005 & 0.016 & $6|4| 3$ & & not significant & & \\
\hline Synaptotagmin-1 & P46096 & Syt1 & 2 & $6 \mid 7$ & 1.09 & $\Delta$ & 0.001 & 0.004 & $5 \mid 6$ & 1.11 & 0.0016 & 0.0112 & $\boldsymbol{\Delta}^{* *}$ \\
\hline
\end{tabular}


Table 2 Significantly changed proteins identified using label-based LC-SRM in the frontal cortex and hippocampus of the NR1 ${ }^{\text {neo- }--}$ ( $n=12$ ) compared to wildtype mice $(\mathbf{n}=\mathbf{1 2})$ (Continued)

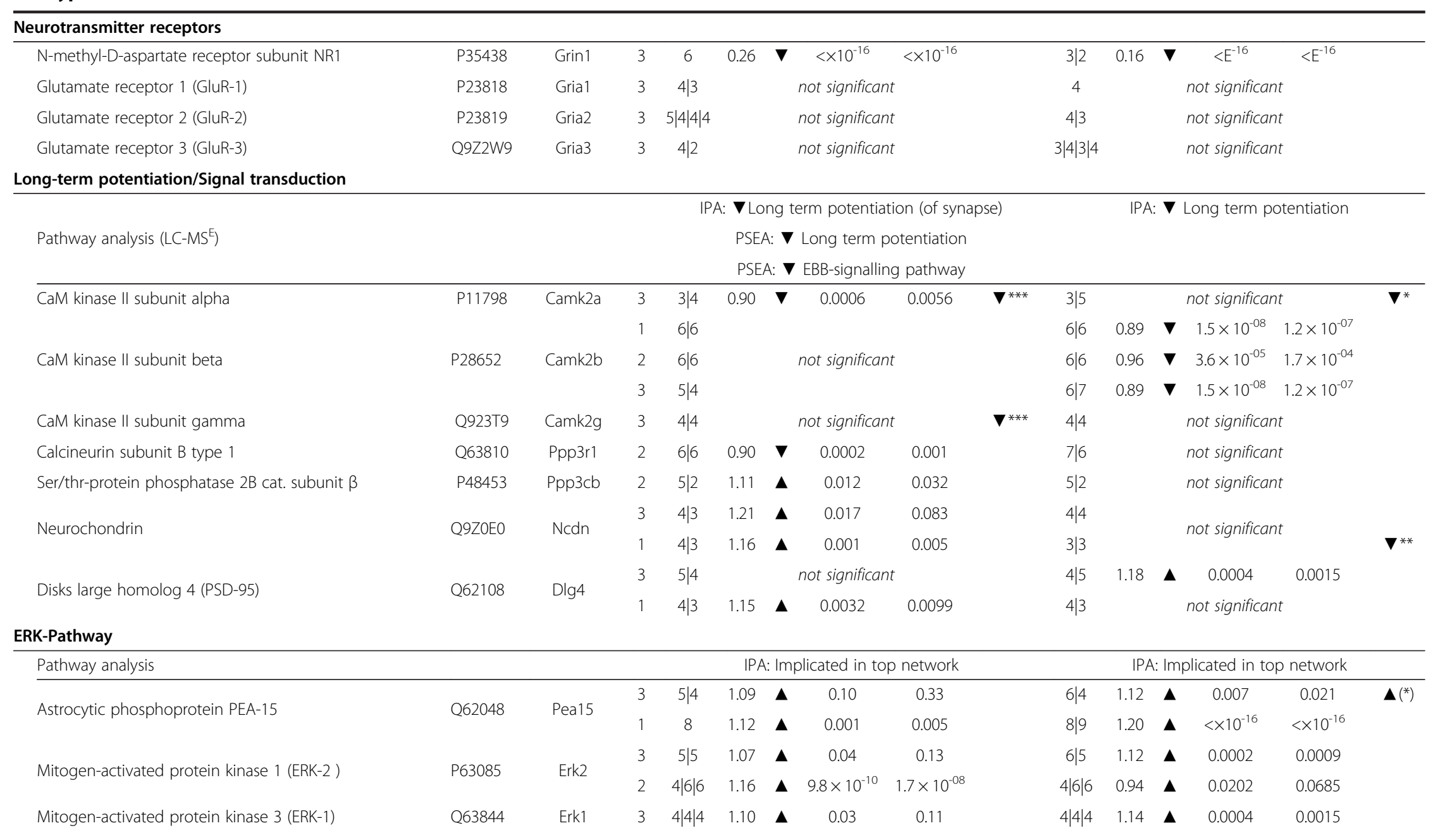


Table 2 Significantly changed proteins identified using label-based LC-SRM in the frontal cortex and hippocampus of the NR1 ${ }^{\text {neo- }-/-}(\mathrm{n}=12)$ compared to wildtype mice $(\mathbf{n}=\mathbf{1 2})$ (Continued)

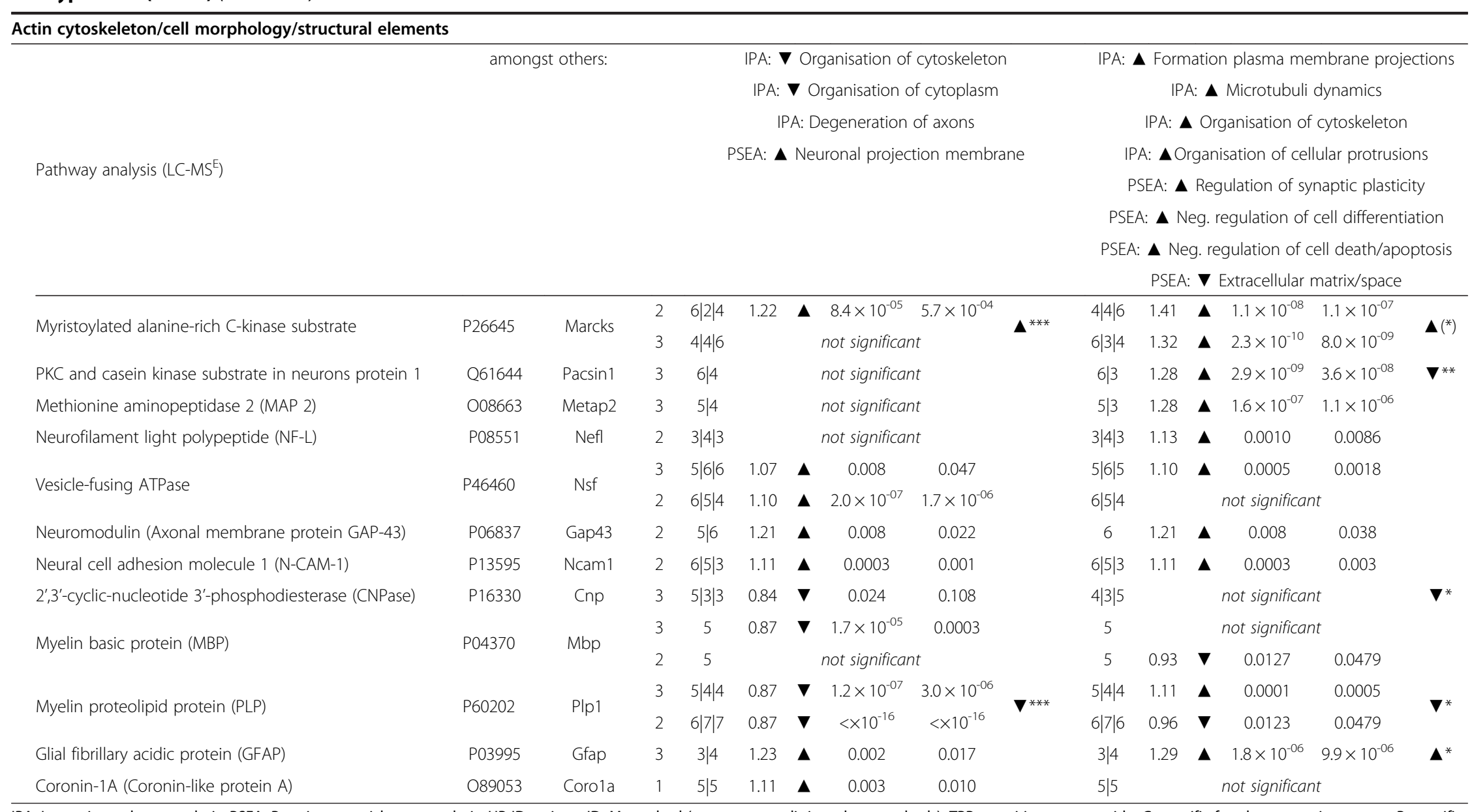

IPA, Ingenuity pathway analysis; PSEA, Protein set enrichment analysis; UP-ID, uniprot-ID; M, method (assays were split into three methods); TPP, transitions per peptide; G, specific for glutamatergic neurons; B, specific

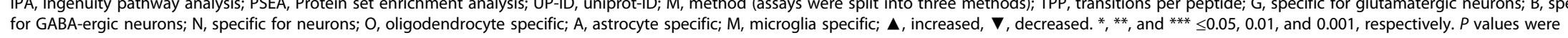
determined using SRMstats and corrected $\left(P^{*}\right)$ to control for multiple hypothesis testing [37]. 
cortex and to a lesser extent in the hippocampus (Table 2). Myelin integrity is crucial for functional neuro-circuitry and perturbations in myelin either during or after neuronal development leads to neurological deficits [78]. The findings are consistent with reports of abnormal myelination in BA10 of SZ, BD [79], and ASD patients $[71,80]$. Interestingly, effects on glutamate signalling have already been linked to oligodendrocyte dysfunction. Rat brains exposed prenatally to the NMDAR antagonist phencyclidine show reduced levels of oligodendrocyte progenitors [81], resulting in fewer differentiated mature oligodendrocytes capable of producing myelin. Our results provide further evidence of the role of glutamate and its receptors in white matter abnormalities and dysfunction in neurodevelopmental and psychiatric disorders.

Serum profiling also identified an overall decrease in chemokines (Table 1) generally associated with an antiinflammatory status reflective of an anti-oxidative state [82], which is supported by an increase in glutathione Stransferase levels in the NR1 $1^{\text {neo-/- }}$ model. Centrally, chemokine signalling regulates essential processes for the establishment of neural networks such as neuronal migration and axon wiring [83]. Decreased chemokine functioning has been linked to deficits in social interaction and an increased repetitive behaviour phenotype, as reported in ASD and other neuropsychiatric disorders [84]. Furthermore, we detected decreased levels of leptin. Leptin facilitates hippocampal synaptic plasticity via enhanced NMDAR-mediated $\mathrm{Ca}^{2+}$-influx [85]. Impairment of this process might contribute to the cognitive deficits by inducing rapid alterations in hippocampal dendritic morphology and synaptic density [85].

The brain proteomic profiling study also highlights a link between NMDAR and purinergic signalling by identifying corresponding alterations in the hippocampus (Table 2 and Figure 3). Purines play a major role in neurotransmission and neuromodulation with their effects being mediated by the purine and pyrimidine receptor subfamilies P1, P2X, and P2Y. Purinergic signalling is associated with learning and memory $[86,87]$ and locomotor activity, in line with the hippocampal specificity observed in our analysis. At a clinical level, it has been shown that antipsychotics, such as haloperidol, chlorpromazine, and fluspirilen, inhibit ATP-evoked responses mediated by P2X receptors $[88,89]$. Hypotheses of dysfunctional purinergic signalling have been put forward for psychiatric disorders [90] and ASD [91]. Applied to a maternal immune activation mouse model of ASD, anti-purinergic therapy has been found to reverse core social deficits and sensorimotor coordination abnormalities while, at the same time, normalizing ERK1/2 and CAMK2 signal transduction abnormalities [92]. ERK1/2 and CamK2 pathways are essential components of NMDAR-related signal transduction and were found to be increased, resp. decreased in the NR1 $1^{\text {neo-l- }}$ mouse.

The ERK signalling pathway comprises phosphorylation of proteins involved in transcriptional and translational regulation, dendritic arborisation, cellular excitability, long-term potentiation and depression, neuronal survival, synaptogenesis, and neurotransmitter release [93], and our findings indicated that all of these pathways were altered in the $\mathrm{NR} 1^{\text {neo-l- }}$ mouse. Upstream, ERK activation is regulated by the activity of dopamine, serotonin, and glutamate receptors [94], which are modulated by antipsychotics [95]. Antipsychotics have been shown to differentially mediate the ERK cascade in vitro and in vivo, dependent on cell and tissue type [96-99]. Clozapine differs from all other antipsychotics by recruiting the EGF-receptor to signal to ERK [100,101], which contributes to clozapine's broad clinical phenotype. Consistent with this, we found evidence for elevated serum levels of EGF. Further evidence for the involvement of ERK signalling in the pathogenesis of psychiatric spectrum is provided by post mortem brain studies [102,103]. The ERK signalling pathway has also been implicated in the mechanism of action of mood stabilizers [104] and social behaviour [105], and extensively for ASD [106,107]. Interestingly, clozapine has also been shown to be efficacious in the treatment of ASD patients [108]. Remarkably, a recent study showed that the transcriptional regulation exerted by a diverse set of ASD-associated genes (FMR1, TSC1, PTEN, etc.) converges on ERK signalling [109].

With this comprehensive proteomic investigation, we found that the knockdown of one single protein can lead to multiple alterations in a range of signalling pathways both in the central nervous system as well as in blood serum. In brain tissue, we found pyruvate kinase to be one of the most robust changes in the NR1 $1^{\text {neo-/- }}$ mouse, consistent with studies showing increased levels of this key glycolytic enzyme in SZ [110] and in a phencylidine rat model [111]. Furthermore, we found decreased levels of CamKIIa, which is associated with cognitive impairment [112]. Another prominent change was a 20 to $30 \%$ increase in MARCS in both regions. MARCS, regulated by calcium-calmodulin and PKC signalling, is a filamentous actin-crosslinking protein involved in cytoskeleton remodelling [113]. Hence, it is involved in the maintenance of dendritic spines and contributes to PKC-dependent morphological plasticity [114] and memory function $[115,116]$. Furthermore, MARCS is specifically degraded in response to intense NMDAR stimulation. Since the NR1 $1^{\text {neo-l- }}$ mouse expresses only $10 \%$ of the NR1 subunit, less NMDAR can be stimulated compared to the WT. This is consistent with our results of increased MARCS levels in the NR1 $1^{\text {neo-l- }}$ model [117]. MARCS has been implicated in proteomic studies of SZ 
patients [111] and decreased MARCS levels have been associated with both lithium and valporate treatment [118].

\section{Conclusions}

In summary, our results provide the first proteomic characterization of the NR1 $1^{\text {neo-l- }}$ mouse model to date, investigating both brain and serum changes associated with NMDAR hypofunction. We provide evidence for a strong link of neurotransmitter dysfunction and changes in circulating bioactive peptides and proteins, which are implicated in altered brain function and synaptic remodelling. The results presented here provide novel insights into the molecular consequences of altered NMDAR function, such as SZ and ASD, and into the assumed disease mechanisms of psychiatric disorders in which perturbations of NMDAR function are likely to play an important role.

Taken together, the current findings provide further support that neuropsychiatric disorders present with prominent systemic changes affecting a wide range of tissues outside the brain which could represent diagnostic and surrogate markers for personalised medicine approaches in the field of psychiatry.

\section{Additional files}

Additional file 1: Table S2. Full information for all analytes measured using multiplexed immunoassay profiling.

Additional file 2: Table S1. Full information for all transitions measured in the multiplexed SRM-assay.

Additional file 3: Table S3. Biological classification of differentially expressed proteins identified in the frontal cortex and hippocampus of the NR1 $1^{\text {neo-l- }}$ mouse.

Additional file 4: Table S4. Information Ingenuity Pathway Analysis (IPA).

\section{Abbreviations}

ASD: Autism spectrum disorders; FDR: False discovery rate; GO: Gene ontology; NMDA: N-methyl-D-aspartate; NMDAR: NMDA-receptor; LC-MS: Liquid chromatography-mass spectrometry in expression mode; MARCS: Myristoylated alanine-rich C-kinase substrate; NR1 ${ }^{\text {neo-l- }}$ mouse: NMDA-receptor NR1 subunit knockdown mouse; SRM: Selected reaction monitoring; SZ: Schizophrenia; UPLC: Ultra-performance liquid chromatography; WT: Wildtype.

\section{Competing interests}

SB is a consultant for Myriad-RBM. This does not affect policies regarding sharing of data and materials specified by this journal. None of the other authors declare a conflict of interest.

\section{Authors' contributions}

HW carried out the label-free LC-MSE experiments, designed and carried out the SRM experiments, and performed all statistical and bioinformatic data analyses. HW prepared the figures and tables and drafted the manuscript. SB, CML, and EHFW conceived the study and participated in its design and coordination. SB, PCG, and HR helped to interpret the results and drafted and edited the manuscript. All authors read and approved the final manuscript.

\section{Acknowledgements}

This research was kindly supported by the Stanley Medical Research Institute (SMRI), the Innovative Medicines Initiative for Novel Methods leading to New
Medications in Depression and Schizophrenia (IMI NEWMEDS), the Dutch Fund for Economic Structure Reinforcement ((\#0908) the NeuroBasic PharmaPhenomics project), and the AutismSpeaks grant (\#6009). Additional information is available at Molecular Autism's website.

\section{Author details}

${ }^{1}$ Department of Chemical Engineering and Biotechnology, University of Cambridge, Tennis Court Road, Cambridge CB2 1QT, UK. ${ }^{2}$ AstraZeneca Pharmaceuticals, 1800 Concord Pike, Wilmington, DE 19850, USA.

${ }^{3}$ Department of Neuroscience, Erasmus Medical Center, 3000 Rotterdam, CA, The Netherlands.

Received: 3 April 2014 Accepted: 20 June 2014

Published: 4 July 2014

\section{References}

1. Mohn AR, Gainetdinov RR, Caron MG, Koller BH: Mice with reduced NMDA receptor expression display behaviors related to schizophrenia. Cell 1999, 98:427-436

2. Weickert CS, Fung SJ, Catts VS, Schofield PR, Allen KM, Moore LT, Newell KA, Pellen D, Huang XF, Catts SV, Weickert TW: Molecular evidence of $\mathrm{N}$-methyl-D-aspartate receptor hypofunction in schizophrenia. Mol Psychiatry 2012, 18:1185-1192.

3. Eastwood SL, Kerwin RW, Harrison PJ: Immunoautoradiographic evidence for a loss of alpha-amino-3-hydroxy-5-methyl-4-isoxazole propionatepreferring non-N-methyl-D-aspartate glutamate receptors within the medial temporal lobe in schizophrenia. Biol Psychiatry 1997, 41:636-643.

4. Tamminga CA: Schizophrenia and glutamatergic transmission. Crit Rev Neurobiol 1998, 12:21-36.

5. Lahti AC, Koffel B, LaPorte D, Tamminga CA: Subanesthetic doses of ketamine stimulate psychosis in schizophrenia. Neuropsychopharmacology 1995, 13:9-19.

6. Hyttel J: Dopamine-receptor binding and adenylate-cyclase activity in mouse striatal tissue in the supersensitivity phase after neuroleptic treatment. Psychopharmacology (Berl) 1978, 59:211-216.

7. Ereshefsky L, Watanabe MD, Tran-Johnson TK: Clozapine: an atypical antipsychotic agent. Clin Pharm 1989, 8:691-709.

8. Gingrich JA, Caron MG: Recent advances in the molecular biology of dopamine receptors. Annu Rev Neurosci 1993, 16:299-321.

9. Dzirasa K, Ramsey AJ, Takahashi DY, Stapleton J, Potes JM, Williams JK Gainetdinov RR, Sameshima K, Caron MG, Nicolelis MA: Hyperdopaminergia and NMDA receptor hypofunction disrupt neural phase signaling. J Neurosci 2009, 29:8215-8224.

10. Silverman JL, Yang M, Lord C, Crawley JN: Behavioural phenotyping assays for mouse models of autism. Nat Rev Neurosci 2010, 11:490-502.

11. Gandal MJ, Anderson RL, Billingslea EN, Carlson GC, Roberts TPL, Siegel SJ: Mice with reduced NMDA receptor expression: more consistent with autism than schizophrenia? Genes Brain Behav 2012, 11:740-750.

12. Gandal MJ, Edgar JC, Ehrlichman RS, Mehta M, Roberts TPL, Siegel SJ: Validating gamma oscillations and delayed auditory responses as translational biomarkers of autism. Biol Psychiatry 2010, 68:1100-1106.

13. Saunders JA, Tatard-Leitman VM, Suh J, Billingslea EN, Roberts TP, Siegel SJ: Knockout of NMDA receptors in parvalbumin interneurons recreates autism-like phenotypes. Autism Res 2013, 6:69-77.

14. Billingslea EN, Tatard-Leitman VM, Anguiano J, Jutzeler CR, Suh J, Saunders JA, Morita S, Featherstone RE, Ortinski PI, Gandal MJ, Lin R, Liang Y, Gur RE, Carlson GC, Hahn CG, Siegel SJ: Parvalbumin cell ablation of NMDA-R1 causes increased resting network excitability with associated social and self-care deficits. Neuropsychopharmacology 2014, 39:1603-1613.

15. Pozzi L, Dorocic IP, Wang X, Carlen M, Meletis K: Mice lacking NMDA receptors in parvalbumin neurons display normal depression-related behavior and response to antidepressant action of NMDAR antagonists. PLoS One 2014, 9:e83879.

16. Niciu MJ, lonescu DF, Richards EM, Zarate CA Jr: Glutamate and its receptors in the pathophysiology and treatment of major depressive disorder. J Neural Transm 2013, In press.

17. Dang YH, Ma XC, Zhang JC, Ren Q, Wu J, Gao CG, Hashimoto K: Targeting of NMDA receptors in the treatment of major depression. Curr Pharm Des 2014, In press.

18. Purcell $A E$, Jeon $\mathrm{OH}$, Zimmerman AW, Blue ME, Pevsner J: Postmortem brain abnormalities of the glutamate neurotransmitter system in autism. Neurology 2001, 57:1618-1628. 
19. Duffney LJ, Wei J, Cheng J, Liu WH, Smith KR, Kittler JT, Yan Z: Shank3 deficiency induces NMDA receptor hypofunction via an actin-dependent mechanism. J Neurosci 2013, 33:15767-15778.

20. Horder J, Lavender T, Mendez MA, O'Gorman R, Daly E, Craig MC, Lythgoe DJ, Barker GJ, Murphy DG: Reduced subcortical glutamate/glutamine in adults with autism spectrum disorders: a [H-1]MRS study. Translational Psychiatry 2013, 3:e279.

21. Eack SM, Bahorik AL, McKnight SA, Hogarty SS, Greenwald DP, Newhill CE, Phillips ML, Keshavan MS, Minshew NJ: Commonalities in social and non-social cognitive impairments in adults with autism spectrum disorder and schizophrenia. Schizophr Res 2013, 148:24-28.

22. Duncan GE, Moy SS, Perez A, Eddy DM, Zinzow WM, Lieberman JA, Snouwaert JN, Koller BH: Deficits in sensorimotor gating and tests of social behavior in a genetic model of reduced NMDA receptor function. Behav Brain Res 2004, 153:507-519.

23. Bickel S, Lipp HP, Umbricht D: Early auditory sensory processing deficits in mouse mutants with reduced NMDA receptor function. Neuropsychopharmacology 2008, 33:1680-1689.

24. Halene TB, Ehrlichman RS, Liang Y, Christian EP, Jonak GJ, Gur TL, Blendy JA, Dow HC, Brodkin ES, Schneider F, Gur RC, Siegel SJ: Assessment of NMDA receptor NR1 subunit hypofunction in mice as a model for schizophrenia. Genes Brain Behav 2009, 8:661-675.

25. Bodarky CL, Halene TB, Ehrlichman RS, Banerjee A, Ray R, Hahn CG, Jonak G, Siegel SJ: Novel environment and GABA agonists alter event-related potentials in N-methyl-D-aspartate NR1 hypomorphic and wild-type mice. J Pharmacol Exp Ther 2009, 331:308-318.

26. Gandal MJ, Sisti J, Klook K, Ortinski PI, Leitman V, Liang Y, Thieu T, Anderson R, Pierce RC, Jonak G, Gur RE, Carlson G, Siegel SJ: GABAB-mediated rescue of altered excitatory-inhibitory balance, gamma synchrony and behavioral deficits following constitutive NMDAR-hypofunction. Transl Psychiatry 2012, 2:e142.

27. Duncan GE, Inada K, Koller BH, Moy SS: Increased sensitivity to kainic acid in a genetic model of reduced NMDA receptor function. Brain Res 2010, 1307:166-176.

28. Ernst A, Sharma AN, Elased KM, Guest PC, Rahmoune H, Bahn S: Diabetic $\mathrm{db} / \mathrm{db}$ mice exhibit central nervous system and peripheral molecular alterations as seen in neurological disorders. Trans/ Psychiatry 2013, 3:e263.

29. Martins-de-Souza D, de Oliveira Menezes B, dos Santos Farias A, Horiuchi RS, Crepaldi Domingues C, de Paula E, Marangoni S, Gattaz WF, Dias-Neto E, Camillo Novello J: The use of ASB-14 in combination with CHAPS is the best for solubilization of human brain proteins for two-dimensional gel electrophoresis. Brief Funct Genomic Proteomic 2007, 6:70-75.

30. Ernst A, Ma D, Garcia-Perez I, Tsang TM, Kluge W, Schwarz E, Guest PC, Holmes E, Sarnyai Z, Bahn S: Molecular validation of the acute phencyclidine rat model for schizophrenia: identification of translational changes in energy metabolism and neurotransmission. J Proteome Res 2012, 11:3704-3714.

31. Bateman RH, Carruthers R, Hoyes JB, Jones C, Langridge Jl, Millar A, Vissers JP: A novel precursor ion discovery method on a hybrid quadrupole orthogonal acceleration time-of-flight (Q-TOF) mass spectrometer for studying protein phosphorylation. J Am Soc Mass Spectrom 2002, 13:792-803.

32. Lu P, Vogel C, Wang R, Yao X, Marcotte EM: Absolute protein expression profiling estimates the relative contributions of transcriptional and translational regulation. Nat Biotechnol 2007, 25:117-124.

33. Yang X, Levin $Y$, Rahmoune $H$, Ma D, Schoffmann S, Umrania Y, Guest PC, Bahn S: Comprehensive two-dimensional liquid chromatography mass spectrometric profiling of the rat hippocampal proteome. Proteomics 2011, 11:501-505.

34. Krishnamurthy D, Levin Y, Harris LW, Umrania Y, Bahn S, Guest PC: Analysis of the human pituitary proteome by data independent label-free liquid chromatography tandem mass spectrometry. Proteomics 2011, 11:495-500.

35. Ralhan R, Masui O, Desouza LV, Matta A, Macha M, Siu KW: Identification of proteins secreted by head and neck cancer cell lines using LC-MS/MS: Strategy for discovery of candidate serological biomarkers. Proteomics 2011, 11:2363-2376.

36. Clough T, Thaminy S, Ragg S, Aebersold R, Vitek O: Statistical protein quantification and significance analysis in label-free LC-MS experiments with complex designs. BMC Bioinformatics 2012, 13(Suppl 16):S6.

37. Benjamini $Y$, Hochberg $Y$ : Controlling the false discovery rate - a practical and powerful approach to multiple testing. J R Stat Soc Ser B 1995, 57:289-300.
38. Pan CP, Kumar C, Bohl S, Klingmueller U, Mann M: Comparative proteomic phenotyping of cell lines and primary cells to assess preservation of cell type-specific functions. Mol Cell Proteomics 2009, 8:443-450.

39. Zhang YY, Filiou MD, Reckow S, Gormanns P, Maccarrone G, Kessler MS, Frank E, Hambsch B, Holsboer F, Landgraf R, Turck CW: Proteomic and metabolomic profiling of a trait anxiety mouse model implicate affected pathways. Mol Cell Proteomics 2011, 10(12):M111.008110.

40. Falcon S, Gentleman R: Using GOstats to test gene lists for GO term association. Bioinformatics 2007, 23:257-258.

41. Ashburner M, Ball CA, Blake JA, Botstein D, Butler H, Cherry JM, Davis AP, Dolinski K, Dwight SS, Eppig JT, Harris MA, Hill DP, Issel-Tarver L, Kasarskis A, Lewis S, Matese JC, Richardson JE, Ringwald M, Rubin GM, Sherlock G: Gene ontology: tool for the unification of biology. The Gene Ontology Consortium. Nat Genet 2000, 25:25-29.

42. Alexa A, Rahnenfuhrer J, Lengauer T: Improved scoring of functional groups from gene expression data by decorrelating GO graph structure. Bioinformatics 2006, 22:1600-1607.

43. Sturn A, Quackenbush J, Trajanoski Z: Genesis: cluster analysis of microarray data. Bioinformatics 2002, 18:207-208.

44. Picotti $P$, Rinner $O$, Stallmach R, Dautel F, Farrah T, Domon B, Wenschuh H, Aebersold R: High-throughput generation of selected reaction-monitoring assays for proteins and proteomes. Nat Methods 2009, 7:43-46.

45. Lange V, Malmstrom JA, Didion J, King NL, Johansson BP, Schafer J, Rameseder J, Wong CH, Deutsch EW, Brusniak MY, Bühlmann P, Björck L, Domon B, Aebersold R: Targeted quantitative analysis of Streptococcus pyogenes virulence factors by multiple reaction monitoring. $\mathrm{Mol} \mathrm{Cell}$ Proteomics 2008, 7:1489-1500.

46. MacLean B, Tomazela DM, Shulman N, Chambers M, Finney GL, Frewen B, Kern R, Tabb DL, Liebler DC, MacCoss MJ: Skyline: an open source document editor for creating and analyzing targeted proteomics experiments. Bioinformatics 2010, 26:966-968.

47. Farrah T, Deutsch EW, Omenn GS, Campbell DS, Sun Z, Bletz JA, Mallick P, Katz JE, Malmstrom J, Ossola R, Watts JD, Lin B, Zhang H, Moritz RL, Aebersold R: A high-confidence human plasma proteome reference set with estimated concentrations in PeptideAtlas. Mol Cell Proteomics 2011, 10(9):M110.006353

48. Oberg AL, Vitek O: Statistical design of quantitative mass spectrometrybased proteomic experiments. J Proteome Res 2009, 8:2144-2156.

49. Chang CY, Picotti $P$, Huttenhain R, Heinzelmann-Schwarz V, Jovanovic M, Aebersold R, Vitek O: Protein Significance Analysis in Selected Reation Monitoring (SRM) Measurements. Molecular \& Cellular Proteomics 2012, 11:M111.014662.

50. Steeb H, Ramsey JM, Guest PC, Stocki P, Cooper JD, Rahmoune H, Ingudomnukul E, Auyeung B, Ruta L, Baron-Cohen S, Bahn S: Serum proteomic analysis identifies sex-specific differences in lipid metabolism and inflammation profiles in adults diagnosed with Asperger syndrome. Mol Autism 2014, 5:4.

51. Schwarz E, Guest PC, Rahmoune H, Harris LW, Wang L, Leweke FM, Rothermundt $M$, Bogerts B, Koethe D, Kranaster L, Ohrmann P, Suslow T, McAllister G, Spain M, Barnes A, van Beveren NJ, Baron-Cohen S, Steiner J, Torrey FE, Yolken RH, Bahn S: Identification of a biological signature for schizophrenia in serum. Mol Psychiatry 2011, 17:494-502.

52. Chan MK, Guest PC, Levin Y, Umrania Y, Schwarz E, Bahn S, Rahmoune H: Converging evidence of blood-based biomarkers for schizophrenia: an update. Int Rev Neurobiol 2011, 101:95-144.

53. Broek JA, Brombacher E, Stelzhammer V, Guest PC, Rahmoune H, Bahn S The need for a comprehensive molecular characterization of autism spectrum disorders. Int J Neuropsychopharmacol 2013, 17:651-673.

54. Ngounou Wetie AG, Wormwood K, Thome J, Dudley E, Taurines R, Gerlach $M$, Woods AG, Darie CC: A pilot proteomic study of protein markers in autism spectrum disorder. Electrophoresis 2014, In press.

55. Huang JT, Wang L, Prabakaran S, Wengenroth $M$, Lockstone HE, Koethe $D$, Gerth CW, Gross S, Schreiber D, Lilley K, Wayland M, Oxley D, Leweke FM, Bahn S: Independent protein-profiling studies show a decrease in apolipoprotein A1 levels in schizophrenia CSF, brain and peripheral tissues. Mol Psychiatry 2008, 13:1118-1128.

56. La YJ, Wan CL, Zhu H, Yang YF, Chen YS, Pan YX, Feng GY, He L: Decreased levels of apolipoprotein A-I in plasma of schizophrenic patients. J Neural Transm 2007, 114:657-663.

57. Lewis TL, Cao D, Lu H, Mans RA, Su YR, Jungbauer L, Linton MF, Fazio S, LaDu MJ, Li L: Overexpression of human apolipoprotein A-I preserves 
cognitive function and attenuates neuroinflammation and cerebral amyloid angiopathy in a mouse model of Alzheimer disease. $J$ Biol Chem 2010, 285:36958-36968.

58. Zachary l: Neuroprotective role of vascular endothelial growth factor: signalling mechanisms, biological function, and therapeutic potential. Neurosignals 2005, 14:207-221.

59. Stone JM, Morrison PD, Pilowsky LS: Glutamate and dopamine dysregulation in schizophrenia-a synthesis and selective review. J Psychopharmacol 2007, 21:440-452.

60. Moghaddam B: Stress activation of glutamate neurotransmission in the prefrontal cortex: implications for dopamine-associated psychiatric disorders. Biol Psychiatry 2002, 51:775-787.

61. Rubenstein $J$, Merzenich MM: Model of autism: increased ratio of excitation/inhibition in key neural systems. Genes Brain Behav 2003, 2:255-267.

62. Buxbaum JD, Silverman JM, Smith CJ, Greenberg DA, Kilifarski M, Reichert J, Cook EH Jr, Fang Y, Song CY, Vitale R: Association between a GABRB3 polymorphism and autism. Mol Psychiatry 2002, 7:311-316

63. Said CP, Egan RD, Minshew NJ, Behrmann M, Heeger DJ: Normal binocular rivalry in autism: implications for the excitation/inhibition imbalance hypothesis. Vision Res 2012, 77:59-66.

64. Schmeisser MJ, Ey E, Wegener S, Bockmann J, Stempel AV, Kuebler A, Janssen AL, Udvardi PT, Shiban E, Spilker C, Balschun D, Skryabin BV, Dieck S, Smalla KH, Montag D, Leblond CS, Faure P, Torquet N, Le Sourd AM, Toro R, Grabrucker AM, Shoichet SA, Schmitz D, Kreutz MR, Bourgeron T, Gundelfinger ED, Boeckers TM: Autistic-like behaviours and hyperactivity in mice lacking ProSAP1/Shank2. Nature 2012, 486:256-260.

65. Meissirel C, Ruiz de Almodovar C, Knevels E, Coulon C, Chounlamountri N, Segura I, de Rossi P, Vinckier S, Anthonis K, Deleglise B, de Mol M, Ali C, Dassonville K, Loyens E, Honnorat J, Michotte Y, Rogemond V, Smolders I, Voets T, Vivien D, Vanden Berghe P, Van den Bosch L, Robberecht W, Chédotal A, Oliviero S, Dewerchin M, Schmucker D, Thomasset N, Salin P, Carmeliet P: VEGF modulates NMDA receptors activity in cerebellar granule cells through Src-family kinases before synapse formation. Proc Natl Acad Sci U S A 2011, 108:13782-13787.

66. Bayes-Genis A, Conover CA, Schwartz RS: The insulin-like growth factor axis: a review of atherosclerosis and restenosis. Circ Res 2000, 86:125-130.

67. Venkatasubramanian G, Chittiprol S, Neelakantachar N, Naveen MN, Thirthall J, Gangadhar BN, Shetty KT: Insulin and insulin-like growth factor-1 abnormalities in antipsychotic-naive schizophrenia. Am J Psychiatry 2007, 164:1557-1560.

68. Venkatasubramanian G, Chittiprol S, Neelakantachar N, Shetty T, Gangadhar BN: Effect of antipsychotic treatment on Insulin-like Growth Factor-1 and cortisol in schizophrenia: a longitudinal study. Schizophr Res 2010, 119:131-137.

69. Vanhala R, Turpeinen U, Riikonen R: Low levels of insulin-like growth factor-I in cerebrospinal fluid in children with autism. Dev Med Child Neurol 2001, 43:614-616.

70. Riikonen R, Makkonen I, Vanhala R, Turpeinen U, Kuikka J, Kokki H: Cerebrospinal fluid insulin-like growth factors IGF-1 and IGF-2 in infantile autism. Dev Med Child Neurol 2006, 48:751-755.

71. Steinman G: Predicting autism at birth. Med Hypotheses 2013, 81:21-25.

72. Palomino A, Gonzalez-Pinto A, Martinez-Cengotitabengoa M, Ruiz de Azua S, Alberich S, Mosquera F, Matute C: Relationship between negative symptoms and plasma levels of insulin-like growth factor 1 in first-episode schizophrenia and bipolar disorder patients. Prog Neuropsychopharmacol Biol Psychiatry 2013, 44:29-33.

73. O'Kusky JR, Ye P, D'Ercole AJ: Insulin-like growth factor-I promotes neurogenesis and synaptogenesis in the hippocampal dentate gyrus during postnatal development. J Neurosci 2000, 20:8435-8442.

74. Tham A, Nordberg A, Grissom FE, Carlsson-Skwirut C, Viitanen M, Sara VR: Insulin-like growth factors and insulin-like growth factor binding proteins in cerebrospinal fluid and serum of patients with dementia of the Alzheimer type. J Neural Transm Park Dis Dement Sect 1993, 5:165-176.

75. Riikonen R: Insulin-like growth factor delivery across the blood-brain barrier. Potential use of IGF-1 as a drug in child neurology. Chemotherapy 2006, 52:279-281.

76. Shcheglovitov A, Shcheglovitova O, Yazawa M, Portmann T, Shu R, Sebastiano V, Krawisz A, Froehlich W, Bernstein JA, Hallmayer JF, Dolmetsch RE: SHANK3 and IGF1 restore synaptic deficits in neurons from 22q13 deletion syndrome patients. Nature 2013, 503:267-271.
77. Bozdagi O, Tavassoli T, Buxbaum JD: Insulin-like growth factor-1 rescues synaptic and motor deficits in a mouse model of autism and developmental delay. Mol Autism 2013, 4:9.

78. Duncan ID, Lunn KF, Holmgren B, Urba-Holmgren R, Brignolo-Holmes L: The taiep rat: a myelin mutant with an associated oligodendrocyte microtubular defect. J Neurocytol 1992, 21:870-884.

79. Tkachev D, Mimmack ML, Ryan MM, Wayland M, Freeman T, Jones PB, Starkey M, Webster MJ, Yolken RH, Bahn S: Oligodendrocyte dysfunction in schizophrenia and bipolar disorder. Lancet 2003, 362:798-805.

80. Brun CC, Nicolson R, Lepore N, Chou YY, Vidal CN, DeVito TJ, Drost DJ, Williamson PC, Rajakumar N, Toga AW, Thompson PM: Mapping brain abnormalities in boys with autism. Hum Brain Mapp 2009, 30:3887-3900.

81. Lindahl JS, Kjellsen BR, Tigert J, Miskimins R: In utero PCP exposure alters oligodendrocyte differentiation and myelination in developing rat frontal cortex. Brain Res 2008, 1234:137-147.

82. Martinez-Cengotitabengoa M, Mac-Dowell KS, Leza JC, Mico JA, Fernandez M, Echevarria E, Sanjuan J, Elorza J, Gonzalez-Pinto A: Cognitive impairment is related to oxidative stress and chemokine levels in first psychotic episodes. Schizophr Res 2012, 137:66-72.

83. Yang S, Edman LC, Sanchez-Alcaniz JA, Fritz N, Bonilla S, Hecht J, Uhlen P, Pleasure SJ, Villaescusa JC, Marin O, Arenas E: Cxcl12/Cxcr4 signaling controls the migration and process orientation of A9-A10 dopaminergic neurons. Development 2013, 140:4554-4564.

84. Zhan Y, Paolicelli RC, Sforazzini F, Weinhard L, Bolasco G, Pagani F, Vyssotski AL, Bifone A, Gozzi A, Ragozzino D, Gross CT: Deficient neuron-microglia signaling results in impaired functional brain connectivity and social behavior. Nat Neurosci 2014, 17:400-406.

85. Shanley $\sqcup$, Irving AJ, Harvey J: Leptin enhances NMDA receptor function and modulates hippocampal synaptic plasticity. J Neurosci 2001, 21:RC186.

86. Pankratov $\mathrm{V}$, Lalo UV, Krishtal OA: Role for $\mathrm{P} 2 \mathrm{X}$ receptors in long-term potentiation. J Neurosci 2002, 22:8363-8369.

87. Pedrazza EL, Riboldi GP, Pereira GS, Izquierdo I, Bonan CD: Habituation to an open field alters ecto-nucleotidase activities in rat hippocampal synaptosomes. Neurosci Lett 2007, 413:21-24.

88. Inoue K, Koizumi S, Ueno S: Implication of ATP receptors in brain functions. Prog Neurobiol 1996, 50:483-492.

89. Lara DR, Dall'Igna OP, Ghisolfi ES, Brunstein MG: Involvement of adenosine in the neurobiology of schizophrenia and its therapeutic implications. Prog Neuropsychopharmacol Biol Psychiatry 2006, 30:617-629.

90. Le Feuvre RA, Brough D, Touzani O, Rothwell NJ: Role of P2X7 receptors in ischemic and excitotoxic brain injury in vivo. J Cereb Blood Flow Metab 2003, 23:381-384.

91. Rossignol DA, Frye RE: Mitochondrial dysfunction in autism spectrum disorders: a systematic review and meta-analysis. Mol Psychiatry 2011, 17:290-314.

92. Naviaux RK, Zolkipli Z, Wang L, Nakayama T, Naviaux JC, Le TP, Schuchbauer MA, Rogac M, Tang Q, Dugan LL, Powell SB: Antipurinergic therapy corrects the autism-like features in the poly(IC) mouse model. PLoS One 2013, 8:e57380.

93. Engel SR, Creson TK, Hao Y, Shen Y, Maeng S, Nekrasova T, Landreth GE, Manji HK, Chen G: The extracellular signal-regulated kinase pathway contributes to the control of behavioral excitement. Mol Psychiatry 2009, 14:448-461

94. Valjent E, Pascoli V, Svenningsson P, Paul S, Enslen H, Corvol JC, Stipanovich A, Caboche J, Lombroso PJ, Nairn AC, Greengard P, Hervé D, Girault JA: Regulation of a protein phosphatase cascade allows convergent dopamine and glutamate signals to activate ERK in the striatum. Proc Natl Acad Sci U S A 2005, 102:491-496.

95. Miyamoto S, Duncan GE, Marx CE, Lieberman JA: Treatments for schizophrenia: a critical review of pharmacology and mechanisms of action of antipsychotic drugs. Mol Psychiatry 2005, 10:79-104.

96. Ahmed MR, Gurevich W, Dalby KN, Benovic JL, Gurevich EV: Haloperidol and clozapine differentially affect the expression of arrestins, receptor kinases, and extracellular signal-regulated kinase activation. J Pharmacol Exp Ther 2008, 325:276-283.

97. Fumagalli F, Frasca A, Sparta M, Drago F, Racagni G, Riva MA: Long-term exposure to the atypical antipsychotic olanzapine differently up-regulates extracellular signal-regulated kinases 1 and 2 phosphorylation in subcellular compartments of rat prefrontal cortex. Mol Pharmacol 2006, 69:1366-1372. 
98. Cussac D, Duqueyroix D, Newman-Tancredi A, Millan MJ: Stimulation by antipsychotic agents of mitogen-activated protein kinase (MAPK) coupled to cloned, human (h)serotonin $(5-\mathrm{HT})(1 \mathrm{~A})$ receptors. Psychopharmacology (Berl) 2002, 162:168-177.

99. Lu XH, Dwyer DS: Second-generation antipsychotic drugs, olanzapine, quetiapine, and clozapine enhance neurite outgrowth in PC12 cells via $\mathrm{PI} 3 \mathrm{~K} / \mathrm{AKT}$, ERK, and pertussis toxin-sensitive pathways. J Mol Neurosci 2005, 27:43-64.

100. Pereira A, Fink G, Sundram S: Clozapine-induced ERK1 and ERK2 signaling in prefrontal cortex is mediated by the EGF receptor. J Mol Neurosci 2009, 39:185-198.

101. Pereira A, Sugiharto-Winarno A, Zhang B, Malcolm P, Fink G, Sundram S: Clozapine induction of ERK1/2 cell signalling via the EGF receptor in mouse prefrontal cortex and striatum is distinct from other antipsychotic drugs. Int J Neuropsychopharmacol 2011, 15:1149-1160.

102. Yuan P, Zhou R, Wang Y, Li X, Li J, Chen G, Guitart X, Manji HK: Altered levels of extracellular signal-regulated kinase signaling proteins in postmortem frontal cortex of individuals with mood disorders and schizophrenia. J Affect Disord 2009, 124:164-169.

103. Kyosseva SV: Differential expression of mitogen-activated protein kinases and immediate early genes fos and jun in thalamus in schizophrenia. Prog Neuropsychopharmacol Biol Psychiatry 2004, 28:997-1006.

104. Hao Y, Creson T, Zhang L, Li P, Du F, Yuan P, Gould TD, Manji HK, Chen G: Mood stabilizer valproate promotes ERK pathway-dependent cortical neuronal growth and neurogenesis. J Neurosci 2004, 24:6590-6599.

105. Satoh Y, Endo S, Nakata T, Kobayashi Y, Yamada K, Ikeda T, Takeuchi A, Hiramoto T, Watanabe Y, Kazama T: ERK2 contributes to the control of social behaviors in mice. J Neurosci 2011, 31:11953-11967.

106. Yang K, Sheikh AM, Malik M, Wen G, Zou H, Brown WT, Li X: Upregulation of Ras/Raf/ERK1/2 signaling and ERK5 in the brain of autistic subjects. Genes Brain Behav 2011, 10:834-843.

107. Davis E, Fennoy I, Laraque D, Kanem N, Brown G, Mitchell J: Autism and developmental abnormalities in children with perinatal cocaine exposure. J Natl Med Assoc 1992, 84:315-319.

108. Beherec L, Lambrey S, Quilici G, Rosier A, Falissard B, Guillin O: Retrospective review of clozapine in the treatment of patients with autism spectrum disorder and severe disruptive behaviors. J Clin Psychopharmacol 2011, 31:341-344.

109. Lanz TA, Guilmette E, Gosink MM, Fischer JE, Fitzgerald LW, Stephenson DT, Pletcher MT: Transcriptomic analysis of genetically defined autism candidate genes reveals common mechanisms of action. Mol Autism 2013, 4:45.

110. Yang J, Chen T, Sun L, Zhao Z, Qi X, Zhou K, Cao Y, Wang X, Qiu Y, Su M, Zhao A, Wang P, Yang P, Wu J, Feng G, He L, Jia W, Wan C: Potential metabolite markers of schizophrenia. Mol Psychiatry 2011, 18:67-78.

111. Wesseling H, Chan MK, Tsang TM, Ernst A, Peters F, Guest PC, Holmes E, Bahn S: A combined metabonomic and proteomic approach identifies frontal cortex changes in a chronic phencyclidine rat model in relation to human schizophrenia brain pathology. Neuropsychopharmacology 2013, 38:2532-2544

112. Papaleo F, Lipska BK, Weinberger DR: Mouse models of genetic effects on cognition: relevance to schizophrenia. Neuropharmacology 2011, 62:1204-1220.

113. Hartwig JH, Thelen M, Rosen A, Janmey PA, Nairn AC, Aderem A: MARCKS is an actin filament crosslinking protein regulated by protein kinase $C$ and calcium-calmodulin. Nature 1992, 356:618-622.

114. Calabrese B, Halpain S: Essential role for the PKC target MARCKS in maintaining dendritic spine morphology. Neuron 2005, 48:77-90.

115. McNamara RK, Hussain RJ, Simon EJ, Stumpo DJ, Blackshear PJ, Abel T, Lenox RH: Effect of myristoylated alanine-rich $C$ kinase substrate (MARCKS) overexpression on hippocampus-dependent learning and hippocampal synaptic plasticity in MARCKS transgenic mice. Hippocampus 2005, 15:675-683.

116. Sheu FS, McCabe BJ, Horn G, Routtenberg A: Learning selectively increases protein kinase $C$ substrate phosphorylation in specific regions of the chick brain. Proc Natl Acad Sci USA 1993, 90:2705-2709.
117. Graber S, Maiti S, Halpain S: Cathepsin B-like proteolysis and MARCKS degradation in sub-lethal NMDA-induced collapse of dendritic spines. Neuropharmacology 2004, 47:706-713.

118. Lenox RH, McNamara RK, Watterson JM, Watson DG: Myristoylated alanine-rich $C$ kinase substrate (MARCKS): a molecular target for the therapeutic action of mood stabilizers in the brain? J Clin Psychiatry 1996, 57(Suppl 13):23-31. Discussion 32-23.

doi:10.1186/2040-2392-5-38

Cite this article as: Wesseling et al.: Integrative proteomic analysis of the NMDA NR1 knockdown mouse model reveals effects on central and peripheral pathways associated with schizophrenia and autism spectrum disorders. Molecular Autism 2014 5:38.

\section{Submit your next manuscript to BioMed Central and take full advantage of:}

- Convenient online submission

- Thorough peer review

- No space constraints or color figure charges

- Immediate publication on acceptance

- Inclusion in PubMed, CAS, Scopus and Google Scholar

- Research which is freely available for redistribution

Submit your manuscript at www.biomedcentral.com/submit
C) BioMed Central 